\title{
An assessment of latest Cretaceous Pycnodonte vesicularis (Lamarck, 1806) shells as records for palaeoseasonality: a multi-proxy investigation
}

\author{
Niels J. de Winter ${ }^{1, *}$, Johan Vellekoop ${ }^{1,2, *}$, Robin Vorsselmans ${ }^{2}$, Asefeh Golreihan ${ }^{2}$, Jeroen Soete ${ }^{2}$, Sierra V. Petersen ${ }^{3}$, \\ Kyle W. Meyer ${ }^{3}$, Silvio Casadio ${ }^{4}$, Robert P. Speijer ${ }^{2}$, and Philippe Claeys ${ }^{1}$ \\ ${ }^{1}$ Analytical, Environmental and Geo-Chemistry (AMGC), Vrije Universiteit Brussel (VUB), Brussels, Belgium \\ ${ }^{2}$ Department of Earth and Environmental Science, KU Leuven, Heverlee, Belgium \\ ${ }^{3}$ Earth and Environmental Sciences Department, University of Michigan, Ann Arbor, Michigan, USA \\ ${ }^{4}$ Escuela de Geología, Paleontología y Enseñanza de las Ciencias, Universidad Nacional de Río Negro, \\ CONICET, General Roca, Argentina \\ *These authors contributed equally to this work.
}

Correspondence: Niels J. de Winter (niels.de.winter@vub.be)

Received: 26 September 2017 - Discussion started: 11 October 2017

Revised: 4 April 2018 - Accepted: 21 May 2018 - Published: 8 June 2018

\begin{abstract}
In order to assess the potential of the honeycomb oyster Pycnodonte vesicularis for the reconstruction of palaeoseasonality, several specimens recovered from late Maastrichtian strata in the Neuquén Basin (Argentina) were subject to a multi-proxy investigation, involving scanning techniques and trace element and isotopic analysis. Combined CT scanning and light microscopy reveals two calcite microstructures in $P$. vesicularis shells (vesicular and foliated calcite). Micro-XRF analysis and cathodoluminescence microscopy show that reducing pore fluids were able to migrate through the vesicular portions of the shells (aided by bore holes) and cause recrystallization of the vesicular calcite. This renders the vesicular portions not suitable for palaeoenvironmental reconstruction. In contrast, stable isotope and trace element compositions show that the original chemical composition of the foliated calcite is wellpreserved and can be used for the reconstruction of palaeoenvironmental conditions. Stable oxygen and clumped isotope thermometry on carbonate from the dense hinge of the shell yield sea water temperatures of $11^{\circ} \mathrm{C}$, while previous $\mathrm{TEX}_{86}^{H}$ palaeothermometry yielded much higher temperatures. The difference is ascribed to seasonal bias in the growth of $P$. vesicularis, causing warm seasons to be underrepresented from the record, while $\mathrm{TEX}_{86}^{H}$ palaeothermometry seems to be biased towards warmer surface water temperatures. The multi-proxy approach employed here enables us to differen-
\end{abstract}

tiate between well-preserved and diagenetically altered portions of the shells and provides an improved methodology for reconstructing palaeoenvironmental conditions in deep time. While establishing a chronology for these shells was complicated by growth cessations and diagenesis, cyclicity in trace elements and stable isotopes allowed for a tentative interpretation of the seasonal cycle in late Maastrichtian palaeoenvironment of the Neuquén Basin. Attempts to independently verify the seasonality in sea water temperature by $\mathrm{Mg} / \mathrm{Ca}$ ratios of shell calcite are hampered by significant uncertainty due to the lack of proper transfer functions for pycnodontein oysters. Future studies of fossil ostreid bivalves should target dense, foliated calcite rather than sampling bulk or vesicular calcite. Successful application of clumped isotope thermometry on fossil bivalve calcite in this study indicates that temperature seasonality in fossil ostreid bivalves may be constrained by the sequential analysis of well-preserved foliated calcite samples using this method.

\section{Introduction}

The Late Cretaceous is generally considered a greenhouse world (e.g. Hay, 2008). Indeed, reconstructed global mean temperatures and atmospheric $p \mathrm{CO}_{2}$ concentrations for this period generally exceed those of the present-day climate 
(e.g. Berner, 1990; Andrews et al., 1995; Ekart et al., 1999; Hunter et al., 2008; Quan et al., 2009; Wang et al., 2013). As such, the Late Cretaceous may be considered an analogue for climate of the near future if anthropogenic greenhouse gas emissions continue unabated (Hay, 2013; IPCC, 2014; Dlugokencky, 2017). Many studies have yielded reconstructions of Late Cretaceous climates using either climate models or a variety of proxies in temporally long archives, such as deepsea cores and continental sections (Pearson et al., 2001; Huber et al., 2002; Otto-Bliesner et al., 2002; Miller et al., 2003; Friedrich et al., 2012; de Winter et al., 2014; Vellekoop et al., 2016). Yet, although most deep-time climate reconstructions so far have focused on reconstructing mean annual temperatures (MAT), climate change also involves changes in other climate parameters, such as precipitation, seasonality and the frequency of extreme weather events, which all take place on timescales shorter than those that can be resolved in the above mentioned long archives. Therefore, it is important that these climate variations are understood on a shorter timescale.

One way to achieve such high-resolution palaeoclimate and palaeoenvironmental reconstructions is by using marine organisms that grow their shells incrementally. Marine bivalves are excellent palaeoclimate recorders, since they have a broad geographic distribution and because the rapid secretion of their shells allows for the high time resolution needed to resolve climate parameters on a sub-annual scale (e.g. Jones, 1983; Dettman and Lohmann, 1993; Steuber, 1996; Schöne et al., 2005a, b). The relationship between shell chemistry and the environmental conditions in which bivalves grow has been studied intensively (Gillikin et al., 2005a; Elliot et al., 2009; Marali and Schöne, 2015). As a result, many geochemical proxies have been described based on bivalve calcite. Examples include temperature calibrations for $\mathrm{Mg} / \mathrm{Ca}$ and stable oxygen isotope ratios $\left(\delta^{18} \mathrm{O}\right.$; e.g. Klein et al., 1996a; Richardson et al., 2004; Freitas et al., 2008; Wanamaker et al., 2008), tentative salinity calibrations using $\mathrm{Sr} / \mathrm{Ca}$ and the combination of $\mathrm{Mg} / \mathrm{Ca}$ and $\delta^{18} \mathrm{O}$ (Dodd and Crisp, 1982; Klein et al., 1996a; Watanabe et al., 2001) and proxies for palaeoproductivity, such as $\mathrm{Ba} / \mathrm{Ca}$ and $\mathrm{Mn} / \mathrm{Ca}$ (Lazareth et al., 2003; Gillikin et al., 2008).

Despite their potential for high-resolution palaeoenvironmental reconstruction, seasonally resolved bivalve records are rarely combined with longer timescale reconstructions (e.g. Steuber et al., 2005; Schöne et al., 2005c; Harzhauser et al., 2011; Butler et al., 2013; Hallmann et al., 2013). The use of bivalve records for long-term palaeoclimate reconstructions often requires the use of several different bivalve species, in which case species-specific vital effects can complicate the study (Gillikin et al., 2005a, b; de Winter et al., 2017a). Culture experiments in extant bivalve species have shown that palaeoenvironmental proxies in bivalve calcite may be affected by mechanisms that are independent of the environment of the animal and are controlled by parameters such as growth, reproductive cycle and metabolism (the so- called "vital effects"; Dunbar and Wefer, 1984; Weiner and Dove, 2003; Gillikin et al., 2005b; Lorrain et al., 2005; Carré et al., 2005). These vital effects are often species specific and limit the applicability of proxy transfer functions from modern culture studies to multiple species in the same study or to species for which no culture study data are available. The integration of different species of bivalves in palaeoclimate studies is further complicated by the various ecological niches these species of bivalves occupy, resulting in great variability in their direct environments (Chauvaud et al., 2005; Dreier et al., 2014). In addition, bivalves are often, though not exclusively, found in shallow marine and estuarine environments. This further complicates the interpretation of bivalve records in terms of global climate (e.g. Surge et al., 2001; Richardson et al., 2004; Gillikin et al., 2008; Wisshak et al., 2009; Ullmann et al., 2010; Crippa et al., 2016), as these environments are often characterized by large variations in temperature, salinity and water chemistry, making it hard to disentangle the effects of different environmental parameters on geochemical proxies (e.g. Duinker et al., 1982; Morrison et al., 1998; Pennington et al., 2000).

The above-mentioned problem of combining different high-resolution climate records to study climatic variations on a geological timescale can be overcome by combining results from multiple well-preserved bivalve specimens of the same species and in the same geological setting. Several studies have tried such a multi-specimen approach to trace changes in high-resolution climate parameters, such as seasonal variations, over geological timescales (Dettman and Lohmann, 2000; Dettman et al., 2001; Steuber et al., 2005; Gutiérrez-Zugasti et al., 2016). However, such reconstructions require bivalve species that preserve well, are geographically widespread, have a high occurrence frequency over longer timescales and record seasonal-scale variations within their shell. Potential candidate species for such studies are bivalves of the genus Pycnodonte. This genus of oysters (Bivalvia: Ostreoida; Fischer von Waldheim, 1835) is characterized by a well-developed commissural shelf and vesicular shell microstructure (hence the name "honeycomb oyster" or "foam oyster"; Stenzel, 1971; Hayami and Kase, 1992). Members of the genus Pycnodonte are found in geological deposits from the Lower Cretaceous to the Pleistocene. The appearance of Pycnodonte shells in a wide range of palaeolatitudes and geological settings, especially in the Cretaceous, makes them a promising archive for highresolution climate reconstructions (Ayyasami, 2006; Fossilworks, 2017). As mentioned in Titschak et al. (2010), records from large and long-living bivalves, such as Pycnodonte, provide several advantages in comparison with other seasonality archives. They are slow-growing in comparison to other ostreid taxa, have rather limited kinetic effects and disequilibrium fractionation of stable isotopes (McConnaughey 1989; Abele et al., 2009). In addition, Pycnodonte bivalves likely did not have symbionts, in contrast to, for example, tridacnid bivalves (Elliot et al., 2009). This means that $P y$ - 
cnodonte bivalves take up nutrients and other elements directly from their environment, simplifying the interpretation of their shell composition. Their low-Mg calcite shells are less prone to diagenetic alteration than shells made of aragonite or high-Mg calcite (Al-Aasm and Veizer, 1986; Pirrie and Marshall, 1990), and their sedentary life mode ensures that they fossilize in life position. The latter enables the integration of environmental information extracted from the sediments in which they are fossilized into the discussion of their shell chemistry.

The species Pycnodonte vesicularis (Lamarck, 1806) is one of the most common and long-ranging species of Pycnodonte. Therefore, in this study the potential of $P$. vesicularis to be used as a record for sub-annual environmental variability in the Late Cretaceous is explored. The present study focuses on the characteristics of fossil specimens of $P$. vesicularis from the upper Maastrichtian Jagüel Formation of the Bajada de Jagüel section, Argentina (Fig. 1a). A range of qualitative, semi-quantitative and quantitative methods is applied to investigate the nature of the P. vesicularis shell material, shell morphology and its preservation state. The aim of this multi-proxy approach is to characterize the microstructure and chemical composition of the P. vesicularis shell and its ontogenetic development and to assess its potential as a recorder of palaeoseasonality.

\section{The species Pycnodonte vesicularis}

Pycnodonte vesicularis was reclining and inhabited muddy bottoms on the shallow marine shelf with a low sedimentation rate (e.g. Brezina et al., 2014). Individual valves of $P$. vesicularis vary considerably in dimension, outline, convexity, wall thickness, muscle scar position, deepness, shape and the characteristics of chomata (Pugaczewska, 1977; Brezina et al., 2014). This variability depends on the age of the individual and local environmental conditions, especially the substrate. According to Berzina et al. (2014), about onethird of $P$. vesicularis valves at Bajada de Jagüel are mature (gerontic) specimens, characterized by relatively thick valves $(>10 \mathrm{~mm})$ with a well-developed vesicular layer. Given their longer life span, mature specimens of $P$. vesicularis were considered most suitable for the present investigation.

In the past, several studies have attempted to calculate the age of individuals of $P$. vesicularis based on the number of laminae in the complex of lamellar and vesicular layers (Nestler, 1965), or the number of growth lines in the ligament (Müller, 1970). Yet, so far no studies have investigated the potential of $P$. vesicularis shells as palaeoseasonality records based on their geochemical signature. Unfortunately, no extant species of Pycnodonte are known, rendering culture experiments for these species impossible. However, two species of the closely related Neopycnodonte (Stenzel, 1971) are found in deep-sea habitats today (Neopycnodonte cochlear, Poli, 1795, and Neopycnodonte zibrowii; Gofas et al., 2009; Wisshak et al., 2009), whereas the extant pycnodontein genus Hyotissa is characterized by a shallow marine distribution (Titschack et al., 2010). Detailed studies of the shell morphology and chemical composition of $N$. zibrowii and Hyotissa hyotis were reported in Wisshak et al. (2009) and Titschak et al. (2010) respectively and are used as a basis for comparison of the Pycnodonte oyster shells.

\section{Geological background}

\subsection{Palaeogeographical context}

The studied specimens were collected from the Bajada de Jagüel (BJ) section $\left(38^{\circ} 06^{\prime} 10.5^{\prime \prime} \mathrm{S}, 68^{\circ} 23^{\prime} 20.5^{\prime \prime} \mathrm{W}\right)$. The site is situated in the Neuquén Basin in Argentina, which is bordered to the south by the North Patagonian Massif and to the northeast by the Sierra Pintada Massif (Fig. 1b and c). The Bajada de Jaguël section has a palaeolatitude of $\sim 43^{\circ} \mathrm{S} \pm 2^{\circ}$ relative to the palaeomagnetic reference frame of Torsvik et al. (2012) according to http://www.paleolatitude.org/ (last access: 6 June 2018) (van Hinsbergen et al., 2015). A large transgression from the South Atlantic into the basin (Bertels, 2013) occurred from the late Maastrichtian to early Danian, during a time of relative tectonic quiescence and low magmatic activity (Malumian et al., 2011).

\subsection{Palaeoenvironment}

The Maastrichtian mudstones of the Jagüel Fm. are homogeneous and intensely bioturbated, indicating a welloxygenated seafloor, with palaeodepths of approximately 50-75 m (Scasso et al., 2005; Woelders et al., 2017; see also Fig. 1). A coarse-grained, mottled, clayey sandstone bed, 15$25 \mathrm{~cm}$ thick, separates the Maastrichtian and Danian mudstones. This sandstone bed represents the K-Pg boundary and is thought to have resulted from a tsunami wave, related to the Chicxulub impact event (Scasso et al., 2005). During the late Maastrichtian and early Danian, north and central Patagonia experienced a warm, humid climate. Pollen records suggest rainforests, coastal mangrove forests and swamp communities in the region (Baldoni, 1992; Kiessling et al., 2005; Barreda and Palazzesi, 2007; Iglesias et al., 2007; Palazzesi and Barreda, 2007). This vegetation type is classified as megathermal and indicates average air temperature of $24^{\circ} \mathrm{C}$ or higher (Barreda and Palazzesi, 2007; Palazzesi and Barreda, 2007; Barreda et al., 2012). Average annual sea surface temperatures are estimated to have been $26-29^{\circ} \mathrm{C}$ in the latest Maastrichtian at Bajada de Jagüel, based on $\mathrm{TEX}_{86}^{H}$ palaeothermometry (Woelders et al., 2017; Fig. 1d). An average of these TEX ${ }_{86}^{H}$ temperatures weighted by the stratigraphic abundance of $P$. vesicularis (Aberhan and Kiessling, 2014) yields a temperature of $27.3^{\circ} \mathrm{C} \pm 2.5^{\circ} \mathrm{C}$ for the environment of $P$. vesicularis in the Bajada de Jagüel Formation (see SI1 in the Supplement). While hypersaline conditions have been inferred for the northernmost part of the 

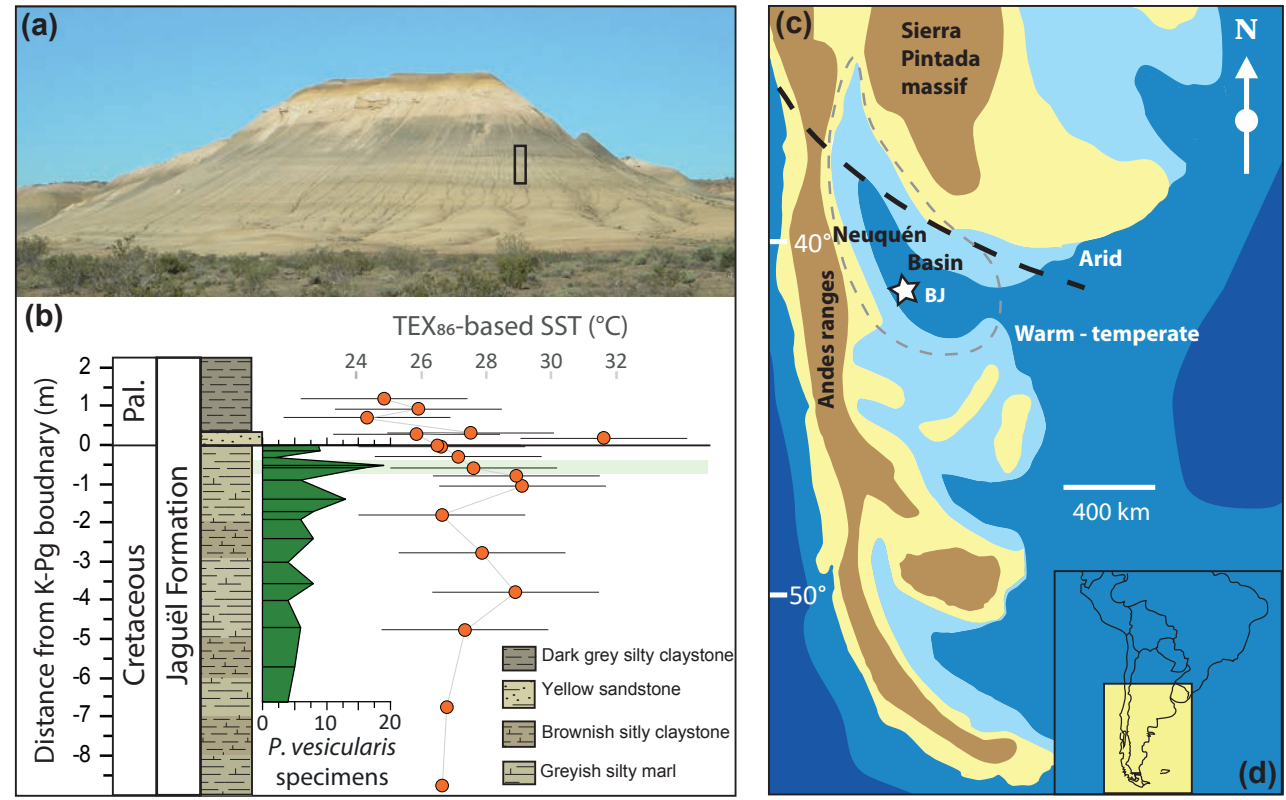

Figure 1. Background information of the studied Pycnodonte vesicularis specimens. (a) The Bajada de Jaguël section in outcrop (BJ; modern location: $38^{\circ} 06^{\prime} 10.5^{\prime \prime} \mathrm{S}, 68^{\circ} 23^{\prime} 20.5^{\prime \prime} \mathrm{W}$; palaeolatitude $=43^{\circ} \mathrm{S}$ ). (b) lithology, stratigraphy and TEX 86 record (Woelders et al., 2017) of the BJ section. The main $P$. vesicularis level is indicated in light green. The abundance of $P$. vesicularis is based on Aberhan and Kiessling (2014). (c) Palaeogeography of study area during the latest Cretaceous. Palaeomap after Scasso et al. (2005) and Woelders et al. (2017). (d) Location of the study area in southern Argentina relative to modern-day South America.

Neuquén Basin, the central part of the Neuquén Basin, where the $\mathrm{BJ}$ site is located, is suggested to have experienced more normal marine conditions. The latter is evidenced by the presence of planktic foraminifera, dinocysts and relatively few terrestrial palynomorphs (Prámparo et al., 1996; Prámparo and Papú 2006; Woelders et al., 2017). Yet, Woelders et al. (2017) inferred enhanced runoff and stratification of the water column at the Bajada de Jaguël site during the late Maastrichtian warming (450-150 kyr before the K-Pg boundary). Hence, salinity may have deviated from normal marine during the lifetime of the Pycnodonte specimens studied here.

\section{Materials and methods}

\subsection{Sample acquisition and preparation}

Seven specimens of Pycnodonte vesicularis were collected from the upper Maastrichtian Jagüel Formation in the Bajada de Jaguël section (Fig. 1), labelled M0, M4, M5, M6, M8, M10 and M11. All shells were collected from the upper $5 \mathrm{~m}$ of below the Cretaceous-Palaeogene boundary (see Fig. 1). The abundance of Pycnodonte in these strata, based on the data of Aberhan and Kiessling (2014), is indicated in Fig. 1. There is a Pycnodonte bed approximately $50 \mathrm{~cm}$ below the $\mathrm{K}-\mathrm{Pg}$ boundary, which is the likely source of most of the specimens. Yet, the specimens studied here were collected as surface finds, so downhill transport cannot be excluded with certainty. Therefore, a more precise stratigraphic position cannot be provided. For associated fauna, see Aberhan et al. (2007), Aberhan and Kiessling (2014) and Woelders et al. (2017).

Four of these specimens (M0, M4, M6 and M11; see Fig. 2) represent completely preserved left valves of mature specimens of $P$. vesicularis (cf. Pugaczewska, 1977), while the remaining three (M5, M8 and M10) were incomplete. Specimens were selected that differ from each other in morphology, body size and extent of biodegradation (e.g. bore holes), to assess both the potentials and possible pitfalls of this taxon as a palaeoseasonality recorder. The four complete shells were cleaned and cast into Araldite ${ }^{\circledR} 2020$ epoxy resin (Araldite, Basel, Switzerland) before being cut along the major growth axis of the shell using a slow rotating rotary saw $(\varnothing 1 \mathrm{~mm})$. A parallel slab was cut out of one-half of the shell, while the other half was preserved (archive half). The resulting thick section, with a typical thickness of $4 \mathrm{~mm}$, was polished using a series of progressively higher-grade silicon carbide polishing disks (up to P2400) to allow for a smooth surface for sampling and imaging. The three incomplete shells were left untreated and were only used for bulk analysis.

\subsection{Colour scanning and microscopy}

Polished surfaces of shell sections were colour scanned at 6400 dpi ( $\sim 4 \mu$ m resolution) using an Epson 1850 flatbed scanner. Shell microstructures were studied and imaged at 
$50 \times$ magnification using an Olympus BX60 optical microscope (KU Leuven, Belgium). In order to study the preservation of pristine calcite in $P$. vesicularis, shell slabs were studied using cathodoluminescence microscopy using a Technosyn Cold Cathodoluminescence model 8200, mark II microscope operated at $16-20 \mathrm{kV}$ electron gun potential, $420 \mu \mathrm{A}$ beam current, 0.05 Torr $\left(6.6 \cdot 10^{-5}\right.$ bar $)$ vacuum and $5 \mathrm{~mm}$ beam width (KU Leuven, Belgium). Cathodoluminescence (CL) refers to the emission of light from material during excitation by an electron beam. The wavelength (i.e. colour) of the emitted light depends on the crystal lattice structure and on activators, i.e. light emitting centres constituted by chemical elements or crystal defects. CL microscopic observations of the shell sections thus enable the recognition of crystal defects and evaluation of the preservation state of the shells (e.g. overgrowth, recrystallization, dissolution), and is used to evaluate whether obtained element concentrations and isotopic ratios reflect the original shell signature (Barbin, 2000).

\subsection{Porosity and trace element analysis}

In order to visualize shell microstructure and the pore network, high-resolution 3-D micro-tomography analysis was carried out on the archive half of Pycnodonte specimens using a General Electric Nanotom micro-CT X-Ray CT scanner (KU Leuven, Belgium). One half-shell was scanned at a $30 \mu \mathrm{m}$ spatial resolution while representative shell pieces of interest were scanned at $1.5 \mu \mathrm{m}$ resolution. The CT images were segmented in MATLAB by applying a dual thresholding algorithm. The shell porosity was rendered in 3-D and labelled in Avizo Fire 7.0. Pore parameters were calculated in Avizo and MATLAB (see SI2 and SI3 in the Supplement for details). Micro-XRF measurements were carried out using a Bruker M4 Tornado micro-XRF scanner (AMGC, VUB, Brussels, Belgium). Details on the setup and methodology of the M4 Tornado $\mu$ XRF scanner can be found in de Winter and Claeys (2016), de Winter et al. (2017b) and in SI4 in the Supplement. Care was taken to limit sampling to the dense calcite in the hinge of the shells, though observations of the microstructure of the shell hinge show that incorporation of vesicular calcite into the profile could not be fully avoided (see Sects. 5.1.1 and 5.1.3).

\subsection{Trace elements in bivalves}

The use of trace element concentrations in fossil bivalve shells as a means of reconstructing palaeoenvironmental conditions is the subject of ongoing debate. As mentioned above, some tentative calibrations have been made that link trace element ratios in shell carbonate to environmental conditions in modern bivalves (e.g. Jones, 1980; Klein et al., 1996a; Freitas et al., 2005; Wanamaker et al., 2008). However, the degree by which the incorporation of these trace element concentrations is controlled by the environment of the bivalve, as opposed to vital effects, is often uncertain (e.g. Weiner and Dove, 2003; Gillikin et al., 2005b; Lorrain et al., 2005). An example is the $\mathrm{Mg} / \mathrm{Ca}$ ratio, which is thought to reflect the calcification temperature of the shell (e.g. Klein et al., 1996a). While the $\mathrm{Mg}$ / Ca palaeothermometer is commonly applied in foraminifera studies (e.g. Elderfield and Ganssen, 2000; Lear et al., 2000), calibrations of this proxy for different bivalve taxa vary widely (Klein et al., 1996a; Vander Putten et al., 2000; Takesue and van Geen, 2004; Freitas et al., 2005; Surge and Lohmann, 2008; Wanamaker et al., 2008; Mouchi et al., 2013; see also de Winter et al., 2017a). Even $\mathrm{Mg} / \mathrm{Ca}$ calibration curves for oyster species within the same genus (Crassostrea virginica in Surge and Lohmann, 2008, and Crassostrea gigas in Mouchi et al., 2013) yield very different results, illustrating that the temperature dependence of $\mathrm{Mg} / \mathrm{Ca}$ ratios in bivalve calcite is not straightforward. Relationships of bivalve $\mathrm{Mg} / \mathrm{Ca}$ ratios with temperature are known to break down during periods of growth stress (Lorens and Bender, 1980; Weiner and Dove, 2003; Takesue and van Geen, 2004). Part of the Mg in bivalve shells is associated with organic molecules in the matrix in the shell rather than being substituted for $\mathrm{Ca}$ in the crystals of bivalve calcite (Lorens and Bender, 1980). In addition, factors determining incorporation of $\mathrm{Mg}$ in bivalve carbonate are partly controlled by physiological processes and are therefore species or even specimen specific (e.g. Freitas et al., 2006, 2008).

Another commonly reported ratio, that of $\mathrm{Sr} / \mathrm{Ca}$, has been demonstrated to co-vary with changes in growth and metabolic rate in some taxa (Klein et al., 1996b; Gillikin et al., 2005b; Lorrain et al., 2005). However, a few studies have shown a positive correlation with water temperature in other species (e.g. Freitas et al., 2005; Wanamaker et al., 2008). These results are somewhat counterintuitive since the partition coefficient of Sr into calcite is negatively correlated with temperature (Rimstidt et al., 1998). The above shows that the extent of vital effects is highly taxon specific and that palaeoclimate reconstructions based on trace element records in bivalve shells need to be interpreted with great care.

Besides sea water temperature, attempts have been made to reconstruct other environmental parameters, such as redox conditions and palaeoproductivity, based on trace element records in bivalves. Examples of such proxies include elements that are enriched in skeletons of primary producers such as Ba (Gillikin et al., 2008; Marali et al., 2017), redox-sensitive elements like Mn (Freitas et al., 2006) and micronutrients such as $\mathrm{Zn}$ and $\mathrm{Cd}$, which are known to be taken up into bivalve shells and whose concentration profiles reflect changes in palaeoproductivity (Carriker et al., 1980a; Calmano et al., 1993; Jackson et al., 1993; Wang and Fisher, 1996; Guo et al., 1997). Seasonal records of these proxies are reproducible between different shells in the same environment (Gillikin et al., 2008). While these proxies have not been explored in detail, their interpretation gives additional information about the ambient sea water chemistry and illustrates the advantage of applying the multi-proxy approach to 

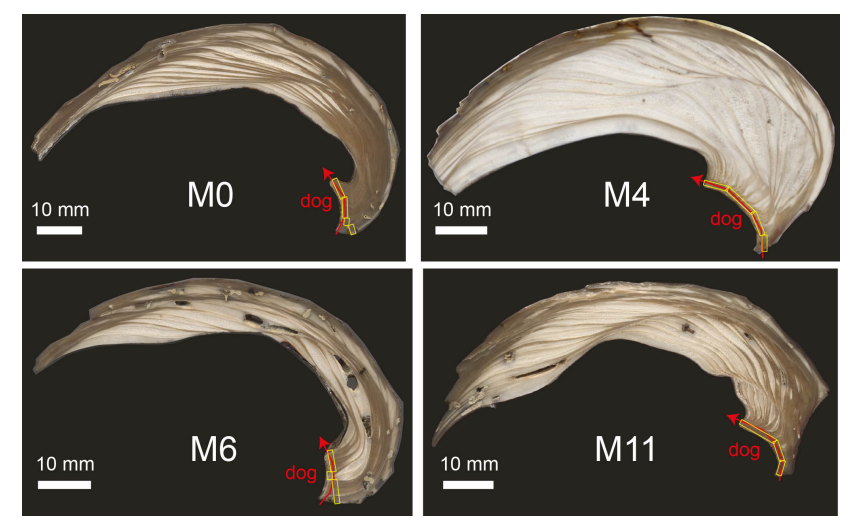

Figure 2. Colour scans of cross sections of the four shells subject to multi-proxy analysis. Red arrows indicate sampling location and direction. Yellow boxes indicate the location of stable isotope transects. XRF sampling is in the direction of growth ("dog").

reconstruct palaeoseasonality from bivalve shells (de Winter et al., 2017a).

\subsection{Stable isotope analyses}

Samples for stable isotope analysis were drilled using a microscope-guided Merchantek drill, coupled to Leica GZ6 microscope, equipped with a $300 \mu \mathrm{m}$ diameter tungsten carbide drill bit. Spatial sample resolutions smaller than the diameter of the drill were obtained by abrading consecutive samples off the side of the sampling front. This was achieved by moving in steps of $100 \mu \mathrm{m}$ along a $\pm 2 \mathrm{~mm}$ wide linear sampling path, oriented parallel to the growth lines of the shell and in the growth direction of the shell (447 measurements in total; see also Van Rampelbergh et al., 2014). Dense, foliated calcite in the hinge of the shells was targeted while sampling for stable isotope analysis, but as a result of the shell structure (see discussion below) the incorporation of some vesicular calcite could not always be excluded. Note that, as a consequence of the abrading sampling strategy, the width of the sampling path for isotope ratio mass spectrometer (IRMS) samples is much larger $(2 \mathrm{~mm})$ than the width of the sampling path of a $\mu$ XRF line scan $(25 \mu \mathrm{m})$. This caused more vesicular calcite to be incorporated into stable isotope measurements than in $\mu \mathrm{XRF}$ measurements, as it was easier to avoid the vesicular microstructure in $\mu \mathrm{XRF}$ line scans.

Aliquots of $\pm 50 \mu \mathrm{g}$ of sampled calcite were allowed to react with $104 \%$ phosphoric acid $\left(\mathrm{H}_{3} \mathrm{PO}_{4}\right)$ at $70{ }^{\circ} \mathrm{C}$ in a $\mathrm{Nu}-$ Carb carbonate preparation device and stable oxygen and carbon isotope ratios $\left(\delta^{13}\right.$ and $\left.\delta^{18} \mathrm{O}\right)$ were measured using a NuPerspective isotope ratio mass spectrometer ( $\mathrm{Nu}$ Instruments Ltd, Wrexham, UK) at the AMGC lab of the VUB. For analytical uncertainties and reproducibility, see SI4 in the Supplement. All stable isotope values are reported in per mille relative to the Vienna Pee Dee Belemnite standard (\%o VPDB). While $\mu \mathrm{XRF}$ and IRMS measurements were car- ried out on the same transect, small differences in the length of the records did occur and these were corrected by linearly rescaling the stable isotope records to match the length of trace element records in the same shell.

\subsection{Clumped isotope analysis}

The stable and clumped isotopic composition of samples from five shells (M4, M5, M8, M10 and M11) was measured at the University of Michigan Stable Isotope Laboratory. Bulk sampling for clumped isotope analysis was carried out in two ways: (1) slabs of dense calcite were broken off the ventral margin of three shells (M5, M8 and M10) and powdered by hand; (2) samples were drilled from the dense hinge area of four shells (M4, M5, M8 and M11). Sample preparation was performed on a manual extraction line following Defliese et al. (2015), with the temperature of the Porapak $^{\mathrm{TM}}$ trap increased to avoid fractionating stable isotope values (Petersen et al., 2016). Aliquots of $3.5-5 \mathrm{mg}$ carbonate powder were reacted with phosphoric acid $\left(\mathrm{H}_{3} \mathrm{PO}_{4}\right)$ at $75^{\circ} \mathrm{C}$, and sample $\mathrm{CO}_{2}$ was analysed on a Thermo Finnigan MAT253 equipped with Faraday cups to measure $m / z$ 44-49. Data presented in the main manuscript were processed using the Santrock/Gonfiantini parameters (Daëron et al., 2016; Schauer et al., 2016) and the high-temperature composite calibration of Defliese et al. (2015). Further details on the measurement and calibration procedure of clumped isotope thermometry are found in SI5 in the Supplement, along with raw data processed using both Santrock/Gonfiantini and Brand parameters.

\section{Results}

\subsection{Pycnodonte vesicularis shell structure}

\subsubsection{Shell microstructures}

An overview of the results of colour scanning, microscopic analyses and $\mu$ XRF mapping on specimen M11 reveals the microstructure of the shells (Fig. 3; SI6 and SI7 in the Supplement). A cross section through the shell in direction of maximum growth (Fig. 3a) shows a layered shell structure with laterally continuous growth increments similar to those in modern ostreids (e.g. Carriker et al., 1980b; Surge and Lohmann, 2008; MacDonald et al., 2009; Ullmann et al., 2013). Growth increments are characterized by an alternation of dense, foliated calcite layers with lighter coloured, more porous, vesicular ("chalky") calcite layers that are characteristic for the family Gryphaeidae (Linnaeus, 1758; Carriker et al., 1980b; Bieler et al., 2004; Surge and Lohmann, 2008). The porosity of these vesicular layers is visualized in microscopic images (Fig. 3d-f). The hinge of the shell is mostly devoid of this vesicular microstructure, but instead consists of closely packed foliated calcite layers (Fig. $3 \mathrm{a}$ and h). However, in parts of the hinge small layers of vesicular calcite are also visible between the foliated layers (Fig. 3h). In places 
where these vesicular layers are interlocked between foliated layers, the transition between the two microstructures is gradual. Further away from the shell hinge, the transitions between foliated calcite and vesicular calcite are sharp and individual layers of foliated and chalky calcite can be very thin $(<30 \mu \mathrm{m}$; Fig. $3 \mathrm{e}-\mathrm{g})$. Pores in the vesicular calcite are heterogeneous in size and shape and can be up to $200 \mu \mathrm{m}$ wide. While the shell structure is in general very well preserved (Fig. 3d-h), it is disturbed in some areas by patches of different texture or holes that have been previously ascribed to boring by polychaete worms (Brezina et al., 2014).

\subsubsection{Porosity}

Micro-CT images of specimen M4 further illustrate the distribution of porosity in the shell (Fig. 4). Porosity analysis based on micro-CT scanning confirms the microscopic observations of porous vesicular calcite and denser foliated calcite layers in the shells. Quantitative analyses of porosity through the shell (porosity logs) on the high-resolution CT scan of a small part of the shell (Fig. 4b) shows that the distribution of porosity strictly relates to growth layering of the shell. The porosity log perpendicular to the layers (Fig. 4e) shows that porosity is almost absent in the foliated calcite layers and reaches up to $65 \%$ of the shell volume in the most porous vesicular layers. Total shell CT scan results reveal that the average porosity in the shell is $21 \%$.

\subsubsection{Chemical heterogeneity and cathodoluminescence}

Heterogeneity in the $P$. vesicularis shell is also evidenced by the distribution of iron $(\mathrm{Fe})$ and manganese $(\mathrm{Mn})$ in the shell, as illustrated by $\mu \mathrm{XRF}$ mapping (Fig. $3 \mathrm{~b}$ and c). The maps show that the vesicular layers are characterized by higher concentrations of $\mathrm{Fe}$ and $\mathrm{Mn}$ than the dense, foliated calcite layers. Parts of the shell that were perforated by bore holes have especially high concentrations of $\mathrm{Fe}$ and $\mathrm{Mn}$, and these holes are surrounded by a corona of elevated $\mathrm{Fe}$ and $\mathrm{Mn}$ concentrations (Fig. 3i-1). A close-up of a shell hinge (Fig. 3b and c) confirms that it consists almost entirely of dense, foliated calcite with low $\mathrm{Fe}$ and $\mathrm{Mn}$ concentrations. It also shows occasional thin layers of vesicular calcite with higher Mn concentrations between foliated calcite layers in the shell hinge (Fig. 3b). The same close-up also illustrates that, due to the spot size of $25 \mu \mathrm{m}$, the method is not able to resolve variations in the concentration of $\mathrm{Fe}$ and $\mathrm{Mn}$ on the scale of fine $(<30 \mu \mathrm{m})$ laminations in the shell hinge. A composite of cathodoluminescence microscopy images of the same area (insert in Fig. 3a) complements $\mu$ XRF mapping by showing in more detail that the foliated calcite of the shell hinge is characterized by microscopic growth increments that show a dull luminescence. At the same time, the vesicular calcite microstructure shows bright luminescence (Fig. 3a, SI6 in the Supplement). Only the largest increments can be distin- guished on the $\mu \mathrm{XRF}$ map, while thin alternations between microstructures are generally too small for the $25 \mu \mathrm{m}$ XRF spot size to detect. In calcite, $\mathrm{Mn}^{2+}$ is the main luminescence activator causing emission of yellow to orange light ( $\sim 620 \mathrm{~nm}$; Machel and Burton, 1991) the intensity of which is positively correlated with the Mn concentration (Lartaud et al., 2010a; Habermann, 2002; Langlet et al., 2006; de Winter and Claeys, 2016). Indeed, brighter layers in the CL image correspond to higher Mn values in the XRF map. An enlarged version of the CL composite shown in Fig. 3 and CL images of other parts of the shells are given in SI6 in the Supplement and XRF Mn and Fe maps of all shells are given in Supplement data 2.

\subsection{Trace element profiles}

Raw results of XRF line scans through all $P$. vesicularis shells featuring in this study are given in SI8 in the Supplement. Quantitative XRF line scans through the hinges yield records of $\mathrm{Ca}, \mathrm{Si}, \mathrm{S} / \mathrm{Ca}, \mathrm{Zn} / \mathrm{Ca}, \mathrm{Sr} / \mathrm{Ca}, \mathrm{Mg} / \mathrm{Ca}, \mathrm{Mn}$ and $\mathrm{Fe}$ in growth direction through the dense hinge area of the shells (Fig. 5). All measured XRF data are directly represented in Fig. 5; only the $\mathrm{Mg} / \mathrm{Ca}$ record is plotted with a three point running average. This smoothing is necessary because the $\mathrm{K} \alpha$ energy in which $\mathrm{Mg}$ fluoresces X-rays is low, causing measurements and quantification of $\mathrm{Mg}$ to be more susceptible to small-scale changes in the sample matrix along the XRF scan, which can be smoothed out by a moving average (see de Winter and Claeys, 2016; de Winter et al., 2017b). Concentrations of calcium (Ca) and silicon ( $\mathrm{Si}$ ) in all shell records generally remain above $38 \mathrm{~m} / \mathrm{m} \%$ and below $0.5 \mathrm{~m} / \mathrm{m} \%$ respectively. In three of the four specimens (M0, M4 and M6), absolute concentrations of Fe and Mn rarely exceed $800 \mathrm{\mu g} \mathrm{g}^{-1}$ (Fig. 5). The iron record of specimen M11 shows maxima often exceeding $2000 \mu \mathrm{g} \mathrm{g}^{-1}$. Fe concentrations in M6 are also elevated in comparison with M0 and M4, leading to the suggestion that there might be a link between the presence of bore holes (observed in M6 and M11) and elevated Fe concentrations. A cross plot in Fig. 6a shows that the concentrations of $\mathrm{Fe}$ and $\mathrm{Mn}$ are weakly correlated in XRF line scan measurements. Furthermore, samples with elevated concentrations of Mn generally have lower $\mathrm{Sr}$ concentrations, especially when Mn concentrations exceed $800 \mathrm{\mu g} \mathrm{g}^{-1}$ (Fig. 6b). Both are a sign of diagenetic alteration because Mn and Fe have been shown to be preferentially enriched in recrystallized shell carbonates, while $\mathrm{Sr}$ is preferentially removed during the recrystallization process (Brand and Veizer, 1980; Al-Aasm and Veizer, 1986a). Trace element profiles through the four $P$. vesicularis specimens show that there is good agreement between shells both in terms of absolute concentration of magnesium $(\mathrm{Mg})$, strontium $(\mathrm{Sr})$, zinc (Zn) and sulfur (S) and their internal variation. Records of ratios of $\mathrm{Mg} / \mathrm{Ca}, \mathrm{Sr} / \mathrm{Ca}, \mathrm{Zn} / \mathrm{Ca}$ and $\mathrm{S} / \mathrm{Ca}$ show quasicyclic oscillations. In records of $\mathrm{Mg} / \mathrm{Ca}$ and $\mathrm{Sr} / \mathrm{Ca}$, these oscillations appear sinusoidal, while records of $\mathrm{Zn} / \mathrm{Ca}$ and 


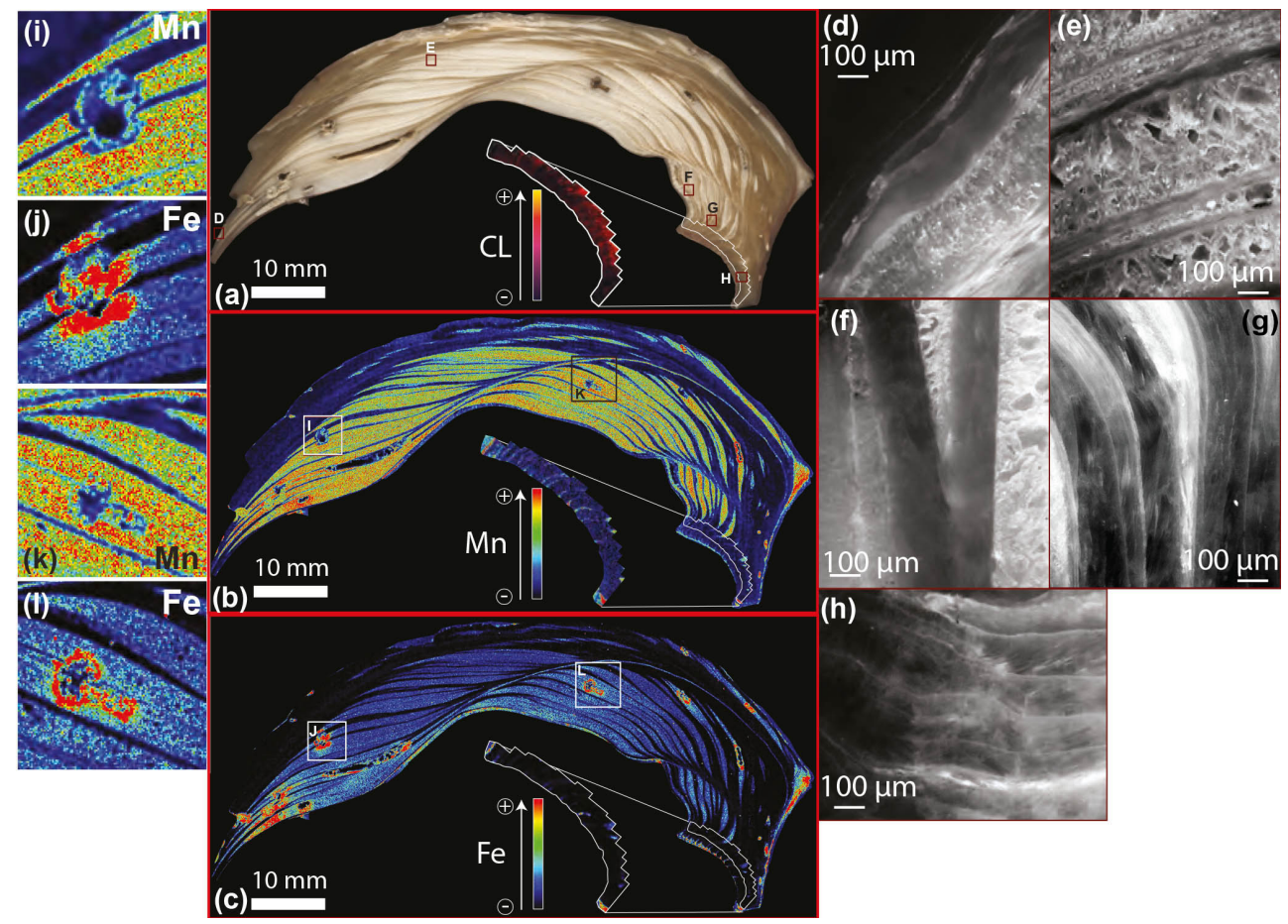

Figure 3. Overview of the results of colour scanning, microscopic analyses and $\mu$ XRF mapping of specimen M11. (a) Colour scan of cross section in growth direction through the shell, with close-up of cathodoluminescence microscopic image of the hinge line. (b) $\mu$ XRF mapping of $\mathrm{Mn}$ the cross section, with close-up of the $\mu \mathrm{XRF}$ map of the hinge line. (c) $\mu$ XRF mapping of Fe the cross section, with close-up of the $\mu \mathrm{XRF}$ map of the hinge line. (d) Micrograph of transitions between foliated and vesicular calcite near the edge of the shell. Note the blocky calcite crystals in the vesicular microstructure. (e) Micrograph of thin, alternating layers of foliated and vesicular calcite. (f) Micrograph showing sharp transitions between dense, foliated calcite and porous vesicular calcite. (g) Micrograph of gradual transitions between foliated calcite and vesicular calcite closer to the hinge. (h) Micrograph of dense, foliated calcite layers in shell hinge line. Note the thin layer of vesicular calcite (white) intercalated between the foliated layers near the bottom of the image. (i-l) Close-ups of $\mu$ XRF mapping of bore holes with coronas of elevated Fe and Mn concentrations.

$\mathrm{S} / \mathrm{Ca}$ are characterized by short-lived increases relative to a baseline value. Trace element ratios generally oscillate around a stable baseline value, though in some cases (e.g. $\mathrm{Sr} / \mathrm{Ca}$ and $\mathrm{Mg} / \mathrm{Ca}$ in M11) there is a slight evolution of this baseline value in the direction of growth.

\subsection{Stable isotope analysis}

\subsubsection{Stable isotope records}

Records of $\delta^{18} \mathrm{O}$ and $\delta^{13} \mathrm{C}$ are plotted together with trace element ratios in Fig. 5. As in trace element records, absolute values as well as internal variation of stable isotope records show good agreement between shells. Values in the $\delta^{18} \mathrm{O}$ record oscillate around a baseline value of $-1.5 \%$. The $\delta^{13} \mathrm{C}$ baseline values are more variable, possibly showing a late ontogenetic trend in M6 and M11, but remaining stable at $2 \%$ in the other specimens. Stable oxygen and carbon isotope records seem to show quasi-periodic variations around these baseline values, with amplitudes of about 1 and $0.5 \%$ o respectively (Fig. 5). Stable oxygen isotope ratios remain between -2.5 and $-0.5 \%$ o for the majority of the records, only dropping below $-3 \%$ in a few measurements in M4, the central part of the M6 record and a few measurements in the youngest part of the M0 record. Similarly, $\delta^{13} \mathrm{C}$ ratios in all shells remain between 1.5 and $3.5 \%$, except for in the case of shell M0. Cross plots between isotope ratios show that samples with exceptionally low $\delta^{18} \mathrm{O}$ values $(<-3 \%$ ) often also exhibit decreased $\delta^{13} \mathrm{C}$ values $(<1.5 \%$; Fig. 6d). This relationship between $\delta^{18} \mathrm{O}$ and $\delta^{13} \mathrm{C}$, which is significant in shells M4, M6 and M11 but not in M0, is often interpreted as a sign of diagenetic alteration (Al-Aasm and Veizer, 1986b; Banner and Hanson, 1990). Therefore, the absence of this relationship in M0 in contrast to the other shells shows that the stable isotope profile from the hinge of shell M0 is least affected by diagenetic alteration. The fact that $\delta^{18} \mathrm{O}$ and $\delta^{13} \mathrm{C}$ values are generally lower in samples with elevated concentrations of Mn and Fe (Fig. 6a and c) supports the hypothesis that these parts of the shell are affected by diagenesis.

\subsubsection{Clumped isotope analysis}

Clumped isotope analyses of ventral margin calcite from three $P$. vesicularis shells from the same palaeoenvironment 

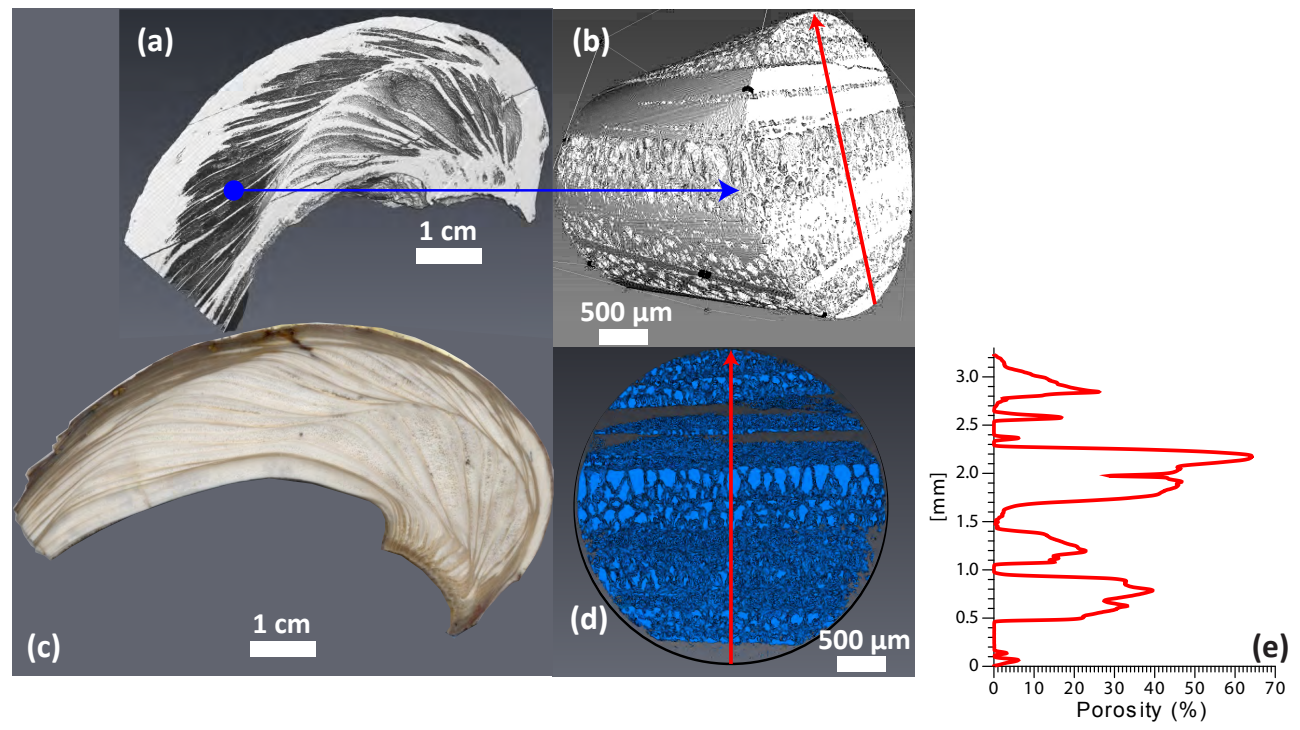

Figure 4. Overview of the results of CT scanning and porosity analysis on specimen M4, with (a) showing an overview of density variations in the shell (white shows dense calcite, darker colours represent porosity). The blue dot shows the location of the part of the shell that was CT scanned at high resolution. (b) shows the shape and density of a part of the shell that was CT scanned with higher spatial resolution as well as the location of the porograph shown in (e). (c) shows a colour scan of the shell cross section. (d) shows a high-resolution cross-section through the shell with porosity in blue (light blue shows porosity, darker colours show dense calcite). The red line is in the same location as in (b). (e) shows a graph of porosity through the high-resolution section perpendicular to the growth layers.

(M5, M8 and M10; see Fig. 1 and Sect. 4.1) yielded $\Delta_{47}$ values of 0.699 to $0.707 \%$, equivalent to a temperature range of $21-25^{\circ} \mathrm{C}$ using the high temperature composite calibration of Defliese et al. (2015; see Table 1). Both reconstructed temperatures and $\delta^{18} \mathrm{O}_{\text {seawater values varied significantly be- }}$ tween these samples, with $\delta^{18} \mathrm{O}_{\text {seawater }}$ ranging from -0.6 in M10 to -2.2 and $-5.9 \%$ in M5 and M8 respectively, likely indicating the influence of altered calcite material. This is supported by shell $\delta^{18} \mathrm{O}$ values, which contain very low values ( -4 to $-7 \%$ o VPDB in M5 and M8) well outside of the range of samples micromilled from the well-preserved hinge carbonate (Fig. 5). The same samples (M5 and M8) also show relatively decreased $\delta^{13} \mathrm{C}$ values $(<1 \%$ ), indicating that these decreased stable isotope ratios are likely indicative of diagenetic alteration. In comparison, samples of the dense hinge calcite from M4, M5, M8 and M11 yielded $\Delta_{47}$ values of 0.725 to $0.746 \%$, corresponding to much cooler temperatures of $9-15^{\circ} \mathrm{C}$ and $\delta^{18} \mathrm{O}_{\text {seawater values ranging from }-1.8}$ to $-3.4 \%$ ( $-2.8 \%$ on average). Shell $\delta^{13} \mathrm{C}$ and $\delta^{18} \mathrm{O}$ values from bulk samples of hinge carbonate resemble values measured in the high-resolution transects, showing that carbonate in the shell hinges is well preserved.

\section{Discussion}

\subsection{Shell preservation}

\subsubsection{Visualization of diagenesis}

Results of CT scanning and microscopy show that while calcite in the vesicular microstructure was affected by recrystallization, the original porosity in $P$. vesicularis shells has been preserved almost completely, and the filling of pores by calcite cementation is relatively uncommon (see Fig. 3de). Microscopic images of the foliated calcite microstructure (e.g. Fig. $3 \mathrm{f}-\mathrm{g}$ ) and comparison with modern oyster studies further show that the elongated crystal microstructure characteristic of pristine foliated shell calcite has not been compromised by diagenesis (Ullmann et al., 2010). Elevated concentrations of $\mathrm{Fe}$ and $\mathrm{Mn}$ in the shells can be used as an indicator for recrystallization, since these elements are incorporated in secondary calcite from reducing pore waters in the sediment surrounding the shell during burial (Al-Aasm and Veizer, 1986a). This makes $\mu$ XRF maps of $\mathrm{Fe}$ and Mn concentrations excellent tools for the assessment of primary calcite preservation. The maps in Fig. $3 \mathrm{~b}$ and $\mathrm{c}$ show that such recrystallization is predominantly observed in the vesicular calcite and that $\mathrm{Fe}$ and $\mathrm{Mn}$ concentrations in foliated calcite layers are low. Coronas of elevated $\mathrm{Fe}$ and $\mathrm{Mn}$ concentrations around bore holes confirm that $\mathrm{Mn}$ and $\mathrm{Fe}$ were leached into the shell through these holes when pore fluids infiltrated the shell and were distributed through the porous vesicular calcite layers. The layered macrostructure of ostreid shells facil- 


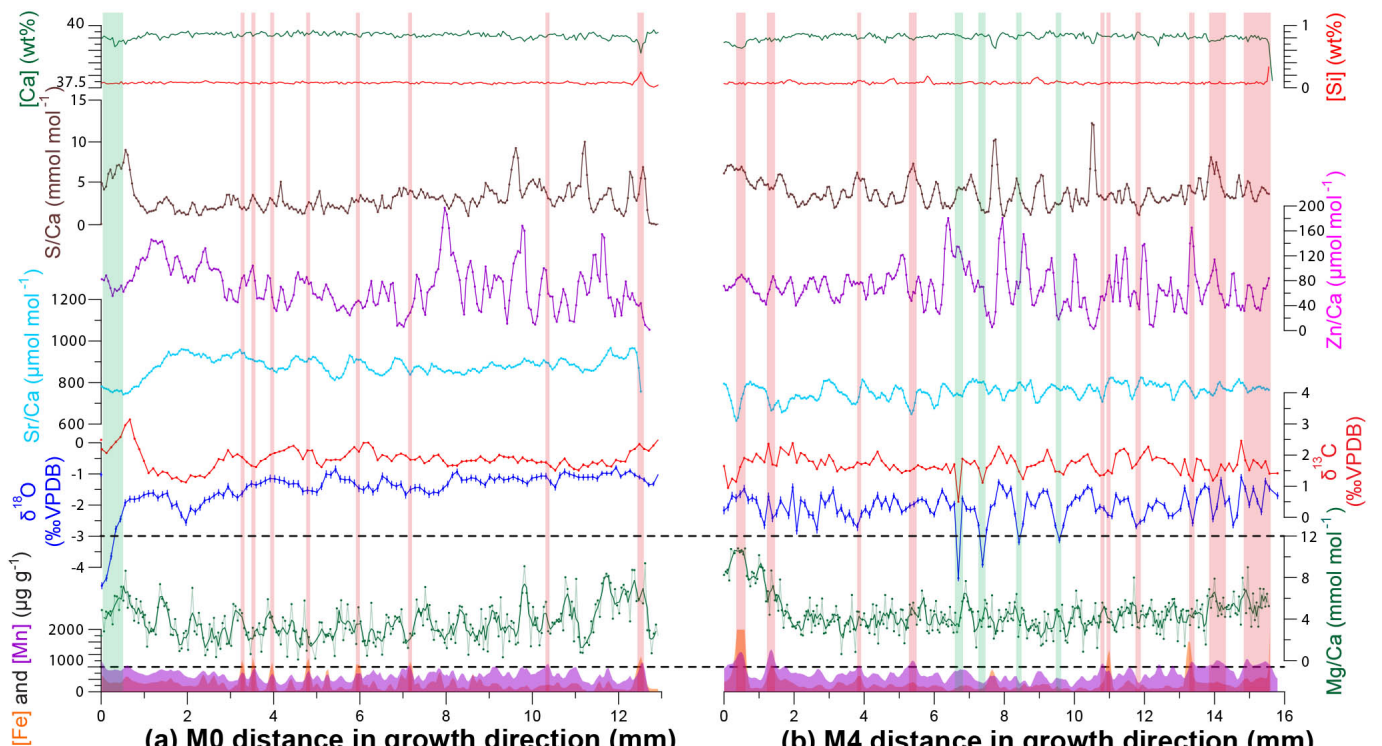

(a) MO distance in growth direction ( $\mathrm{mm}$ )

(b) M4 distance in growth direction $(\mathrm{mm})$

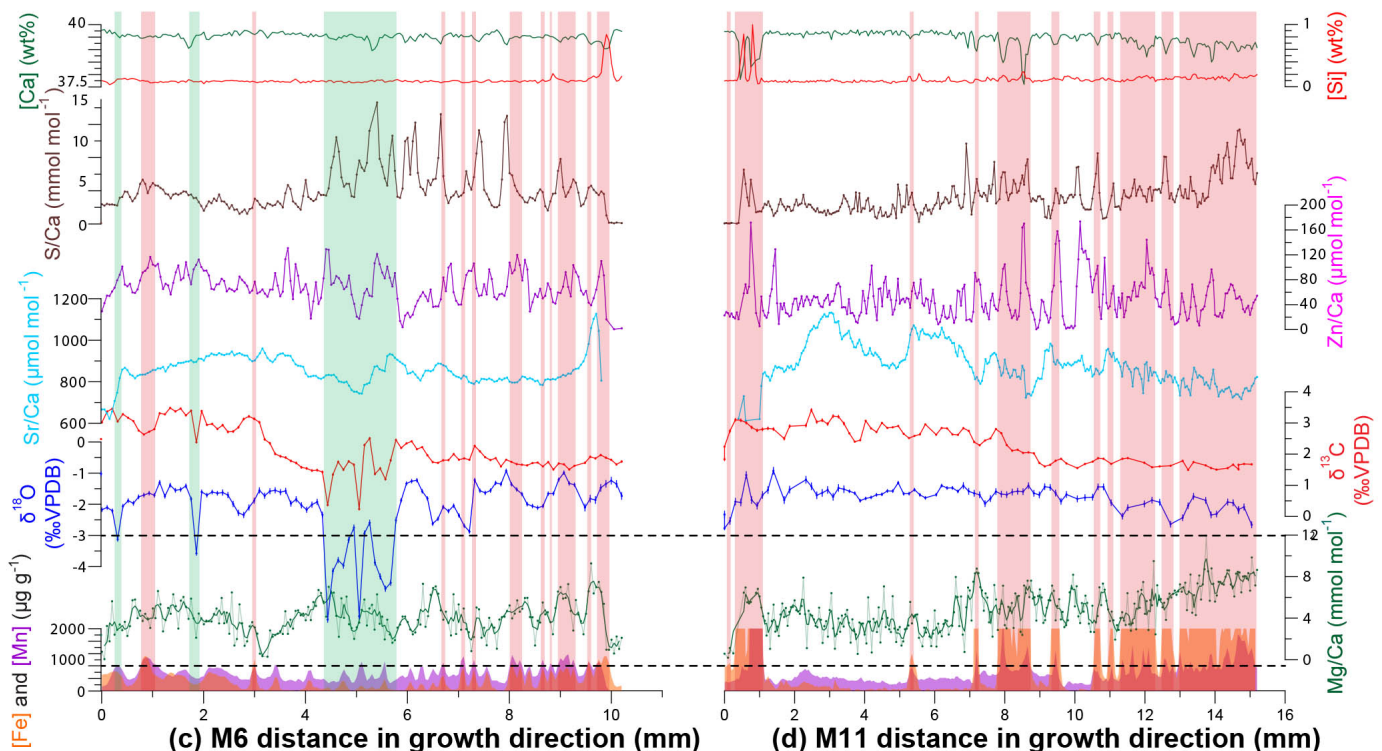

Figure 5. Overview of multi-proxy records through the hinges of four specimens of $P$. vesicularis. From top to bottom, records of Ca (green), $\mathrm{Si}$ (red), S / Ca ratios (brown), Zn / Ca ratios (purple), $\mathrm{Sr} / \mathrm{Ca}$ ratios (light blue), $\delta^{13} \mathrm{C}$ (red), $\delta^{18} \mathrm{O}$ (blue), $\mathrm{Mg} / \mathrm{Ca}$ (green), Mn (purple) and $\mathrm{Fe}$ (orange) are shown. Red arrows in Fig. 2 indicate the direction of sampling. Vertical bars indicate parts of the records that were affected by diagenesis based on $\mathrm{Mn}$ and Fe concentrations (red bars) and stable isotope ratios (green bars). Note that the vertical scale of the Mn and Fe plots is clipped at $2000 \mu \mathrm{gg}^{-1}$.

itated this penetration of pore fluids. The fact that shells M6 and M11, containing the most bore holes (see Fig. 2), have the highest Mn and Fe values (Fig. 5) supports this hypothesis. CL microscopy images showing minimal dull luminescence in the foliated calcite and bright luminescence in vesicular calcite confirm leaching of $\mathrm{Mn}$ and $\mathrm{Fe}$ into the shells (Barbin, 2000). Brightly luminescing laminae between foliated calcite layers in the shell hinge are associated with peaks in Mn and Fe observed in the $\mu$ XRF profiles of M11 (Fig. 5). Comparison between the CL composite and the $\mu \mathrm{XRF}$ map shows that while $\mu \mathrm{XRF}$ mapping does pick up large-scale diagenetic features in the shell, it fails to reveal most of the small layers intercalated between foliated calcite layers in the shell hinge because they are smaller than the spot size of the $\mu \mathrm{XRF}$ scanner $(25 \mu \mathrm{m})$. This illustrates that $\mu \mathrm{XRF}$ mapping is a useful tool for screening diagenetic overprint, but fails to pick up the fine details that are visualized by CL microscopy. Similarly, Mn and Fe profiles in $\mu \mathrm{XRF}$ line scanning will miss or average out the small layers of vesicular calcite present in some parts of the shell hinges of $P$. vesicularis and CL microscopy remains a necessary tool for thorough screening for diagenesis. 
Table 1. Overview table of stable and clumped isotope results in this study. Rows highlighted with bold values samples from the ventral margin of the shells (which contain vesicular calcite). Rows without bold values represent samples of the dense, foliated shell hinge. Note that for some shells (M5 and M8) both the ventral margin and the shell hinge were measured. Columns labelled " $\delta{ }^{13} \mathrm{C}_{\text {record" }}$ and " $\delta{ }^{18} \mathrm{O}_{\text {record" }}$ contain averages of the high-resolution stable isotope records measured in the shell hinges (if available, Fig. 5). The bottom two rows contain average $\Delta_{47}$ and $\delta^{18} \mathrm{O}_{\mathrm{sw}}$ values of shell hinge and ventral margin (bold) samples, highlighting the difference between the two sampling strategies.

\begin{tabular}{|c|c|c|c|c|c|c|c|c|c|}
\hline $\begin{array}{l}\text { Shell } \\
\text { name }\end{array}$ & $\begin{array}{l}\text { Sampling } \\
\text { Location }\end{array}$ & $\mathrm{N}$ & $\begin{array}{r}\delta^{13} \mathrm{C}_{\mathrm{av}} \\
(\mathrm{VPDB}) \\
\pm 1 \sigma\end{array}$ & $\begin{array}{r}\delta^{13} \mathrm{C}_{\text {record }} \\
\quad(\mathrm{VPDB}) \\
\pm \text { season }\end{array}$ & $\begin{array}{r}\delta^{18} \mathrm{O}_{\mathrm{av}} \\
(\mathrm{VPDB}) \\
\pm 1 \sigma\end{array}$ & $\begin{array}{r}\delta^{18} \mathrm{O}_{\text {record }} \\
(\mathrm{VPDB}) \\
\pm \text { season }\end{array}$ & $\begin{array}{r}\mathrm{D} 47_{\mathrm{av}} \\
\pm 1 \sigma\end{array}$ & $\begin{array}{l}\mathrm{T}_{\mathrm{av}} \\
\left({ }^{\circ} \mathrm{C}\right) \\
\pm 1 \sigma\end{array}$ & $\begin{array}{r}\delta^{18} \mathrm{O}_{\mathrm{sw}} \\
\quad \pm 1 \sigma\end{array}$ \\
\hline M0 & Shell hinge & & & $1.91 \pm 0.38$ & & $-1.43 \pm 0.35$ & & & \\
\hline M4 & Shell hinge & 3 & $1.74 \pm 0.10$ & $1.73 \pm 0.32$ & $-2.42 \pm 0.12$ & $-1.99 \pm 0.72$ & $0.725 \pm 0.008$ & $15.2 \pm 2.6$ & $-2.1 \pm 0.7$ \\
\hline M5 & Shell hinge & 3 & $1.70 \pm 0.06$ & & $-2.34 \pm 0.13$ & & $0.746 \pm 0.016$ & $9.0 \pm 4.9$ & $-3.4 \pm 1.2$ \\
\hline M6 & Shell hinge & & & $2.28 \pm 0.23$ & & $-1.88 \pm-0.31$ & & & \\
\hline M8 & Shell hinge & 4 & $1.66 \pm 0.02$ & & $-1.75 \pm 0.06$ & & $0.741 \pm 0.008$ & $10.3 \pm 2.5$ & $-2.5 \pm 0.6$ \\
\hline M11 & Shell hinge & 4 & $2.25 \pm 0.08$ & $2.40 \pm 0.34$ & $-2.58 \pm 0.11$ & $-1.74 \pm 0.30$ & $0.741 \pm 0.007$ & $10.3 \pm 2.1$ & $-3.3 \pm 0.6$ \\
\hline M5 & Ventral margin & 4 & $0.93 \pm 0.15$ & & $-4.36 \pm 0.23$ & & $0.699 \pm 0.007$ & $23.8 \pm 2.5$ & $-2.2 \pm 0.7$ \\
\hline M8 & Ventral margin & 4 & $-0.53 \pm 0.10$ & & $-7.45 \pm 0.32$ & & $\mathbf{0 . 7 0 7} \pm \mathbf{0 . 0 1 2}$ & $21.3 \pm 4.0$ & $-5.9 \pm 1.1$ \\
\hline M10 & Ventral margin & 3 & $2.07 \pm 0.34$ & & $-2.99 \pm 0.23$ & & $0.696 \pm 0.022$ & $25.4 \pm 7.7$ & $-0.6 \pm 1.8$ \\
\hline Average & Shell hinge & 14 & & & & & $0.738 \pm 0.004$ & $11.1 \pm 1.2$ & $-2.8 \pm 0.6$ \\
\hline Average & Ventral margin & 11 & & & & & $\mathbf{0 . 7 0 1} \pm \mathbf{0 . 0 0 7}$ & $23.3 \pm 2.9$ & $-3.1 \pm 2.5$ \\
\hline
\end{tabular}

\subsubsection{Diagenesis in trace element profiles}

Quantitative XRF line scans through the hinges of P. vesicularis show that absolute concentrations of $\mathrm{Fe}$ and $\mathrm{Mn}$ rarely exceed $800 \mu \mathrm{gg}^{-1}$ in all shells except for M11 (Fig. 5). Mn concentrations measured in the hinges are higher than is considered typical for well-preserved bivalve calcite and often exceed the diagenesis threshold of $300 \mu^{g^{-1}}$ proposed by Steuber (1999). However, high concentrations of $\mathrm{Sr}\left(>700 \mu \mathrm{gg}^{-1}\right)$ and $\mathrm{Mg}\left(>1000 \mu \mathrm{gg}^{-1}\right)$, comparatively low Fe concentrations and the observation of nonluminescent, well-preserved foliated calcite crystals (Fig. 3) suggest preservation of the original trace element signature (Veizer, 1983; Al-Aasm and Veizer, 1986a; Steuber, 1999). The fact that parts of shells with more depleted stable isotope ratios and lower $\mathrm{Sr}$ concentrations generally coincide with peaks in Fe and $\mathrm{Mn}$ exceeding $800 \mathrm{\mu g} \mathrm{g}^{-1}$ shows that these results likely signify areas where recrystallization has occurred (see also Figs. 5 and $6 \mathrm{a}-\mathrm{c}$ ). We therefore propose $800 \mu \mathrm{g} \mathrm{g}^{-1}$ as a tentative maximum threshold for $\mathrm{Mn}$ and $\mathrm{Fe}$ concentrations for the preservation of pristine calcite in shells of $P$. vesicularis in this setting, and consider samples exceeding this threshold in concentration for either Mn or $\mathrm{Fe}$ as diagenetically altered. Evidence of such alteration is most common in shells M6 and M11. Except for a few measurements in shells M6 and M11, low Si concentrations and high $\mathrm{Ca}$ concentrations (Fig. 5) indicate limited incorporation of detrital material into the hinge of the shell (see de Winter and Claeys, 2017; de Winter et al., 2017a). Indeed, bore holes filled by detrital material are almost exclusively observed away from the shell hinge and do not significantly influence XRF records (Figs. 2 and 3). From this it follows that the majority of post-mortem alteration of the shells oc- curred through the process of chemical alteration (e.g. recrystallization) rather than physical processes (e.g. predatory burrowing). As described above (see Sect. 5.1.1), the role of bore holes in the shells (especially M6 and M11) in the diagenetic process was predominantly to provide entries through which pore waters could enter to cause recrystallization. Bore holes elsewhere in the shells may lead to migration of fluids through the shell, ultimately resulting in elevated concentrations throughout the shell.

\subsubsection{Diagenesis in stable isotope records}

The majority of the stable isotope ratios measured in the shell records are in agreement with those of well-preserved lowmagnesium calcite fossils (Steuber, 1996, 1999; Tripati et al., 2001) and modern marine mollusc shells (Klein et al., 1996a, b; Goodwin et al., 2001; Lécuyer et al., 2004). $\delta^{18} \mathrm{O}$ and $\delta^{13} \mathrm{C}$ values below -4 and $1 \%$ respectively (a drop of $2-3 \%$ for $\delta^{18} \mathrm{O}$ and $1-2 \%_{\circ}$ for $\delta^{13} \mathrm{C}$ ) in the central part of the M6 shell hinge record are an exception to this and likely represent incorporation of diagenetically altered vesicular calcite into micromilled IRMS samples. The scan image of M6 (Fig. 2) shows that an extension of vesicular calcite into the hinge region resulted in the sampling of vesicular calcite in the stable isotope and trace element records. Similarly, the stable isotope record of specimen M4 was affected by lobes of vesicular calcite extending close to the hinge line. A depletion of both $\delta^{18} \mathrm{O}$ and $\delta^{13} \mathrm{C}$ could potentially also be explained by an input of freshwater into the basin (Gillikin et al., 2006), but the scale of the isotopic shift and the fact that they coincide with increases in vesicular calcite shows that diagenetic alteration is a more likely explanation. Low $\delta^{18} \mathrm{O}$ values in vesicular calcite samples could also suggest that 
(a)

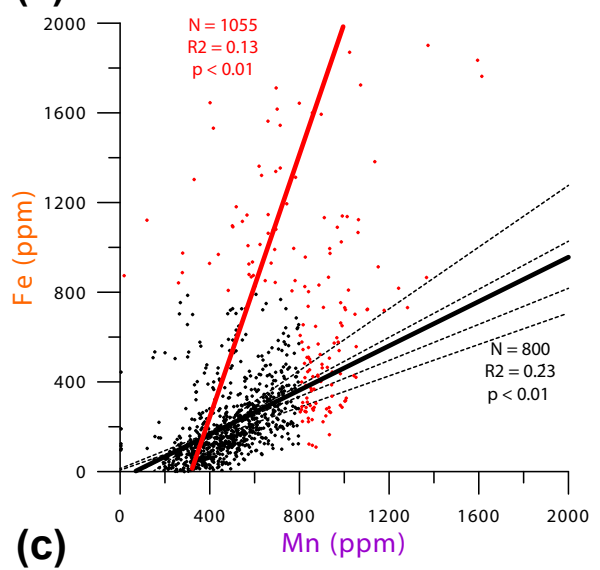

(c)

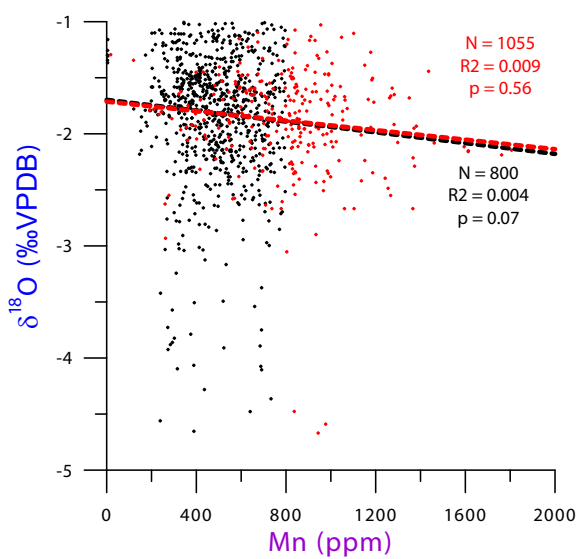

(b)
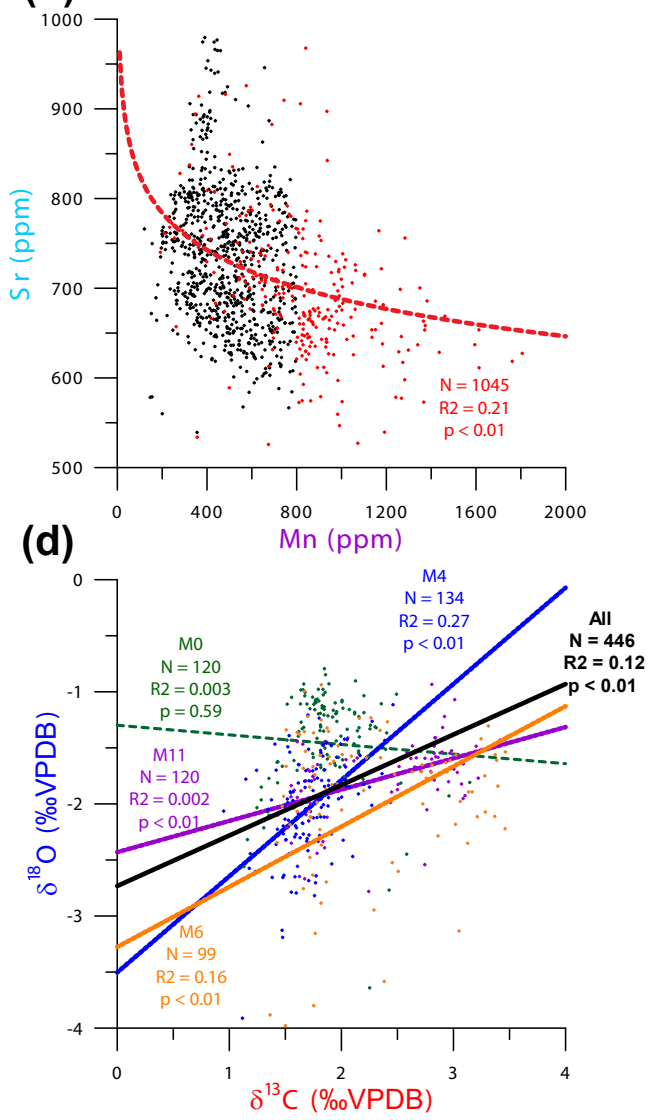

Figure 6. Cross plots between trace element and stable isotope measurements in the shells. Black lines indicate correlations through all measurements, red lines show correlations of diagenetically altered samples (according to the $800 \mu \mathrm{g} \mathrm{g}^{-1}$ threshold for Fe and Mn) and alternatively coloured lines indicate correlations in individual shells. Statistics of the regressions are indicated in matching colours. (a) Fe vs. Mn showing a correlation between concentrations of these elements in all shells. Steeper slopes suggest relatively more Fe is added in diagenetically altered samples. (b) Sr vs. Mn showing decreasing Sr concentrations corresponding to increasing Mn, but only in diagenetically altered samples. No significant correlation was found for pristine samples $\left(R^{2}=0.11, p=0.25\right)$. (c) $\delta^{18} \mathrm{O}$ vs. Mn showing lack of correlation. (d) $\delta^{18} \mathrm{O}$ vs. $\delta^{13} \mathrm{C}$, showing positive correlation in specimens affected by diagenesis and no correlation in $\mathrm{M} 0$, which has pristine values.

this vesicular calcite was initially precipitated in disequilibrium with respect to ambient sea water (Grossman and $\mathrm{Ku}$, 1986; Woo et al., 1993; Steuber, 1999). The latter could be in agreement with the hypothesis that vesicular microstructures in oyster shells are formed by microbes instead of by the bivalve itself (Vermeij, 2014). However, microscopic images of the vesicular microstructure reveal blocky calcite crystals in some areas (Fig. 3e-f), which suggest recrystallization (e.g. Folk and Land, 1975; Schlager and James, 1978). Indeed, the offset in stable isotope ratios of vesicular calcite compared to foliated calcite is not found in modern oyster shells (Surge and Lohmann, 2008; Ullmann et al., 2010). Elevated Mn and Fe concentrations found in XRF mapping (Fig. 3b-c), and the notion that similar chalky or vesicular phases in modern oyster shells are less crystalline and grow faster (Chinzei and Seilacher, 1993; Ullmann et al., 2010), further attest to the fact that vesicular calcite in $P$. vesicularis (and likely in other fossil members of the Gryphaeidae) is more prone to diagenetic alteration than its foliated counterpart, and therefore provides no suitable record of palaeoclimatic information.

This conclusion is also supported by the clumped isotope analysis results. Bulk samples from the ventral margin of the shell (containing more vesicular calcite; see Figs. 2 and 3) contain lower stable isotope ratios and higher reconstructed temperatures than samples from the dense shell hinge (Table 1; Fig. 7). Elevated temperatures in altered samples likely reflect recrystallization of shell material from slightly warmer pore fluids after burial. Comparison of $\Delta_{47}$ with $\delta^{18} \mathrm{O}$ and $\delta^{13} \mathrm{C}$ measurements (Fig. 7) clearly show how the sensitivity of clumped isotope analysis can be used to demonstrate the effect of calcite recrystallization within $P$. vesicularis. Sequential sampling for $\Delta_{47}$ measurements in 
bivalve calcite therefore may provide a useful tool to trace intra-shell variability in preservation and calcification temperature. Temperatures from diagenetic samples (average of $23^{\circ} \mathrm{C}$ ) are relatively low compared to typical pore fluid temperatures measured from diagenetic calcite in other studies (30-120 ${ }^{\circ} \mathrm{C}$; Huntington et al., 2011; Loyd et al., 2012; Dale et al., 2014), and do not deviate much from those of pristine samples $\left(23\right.$ vs. $11^{\circ} \mathrm{C}$; Table 1$)$. This suggests that burial was shallow and recrystallization not extensive. The shallow burial history is also demonstrated by the preservation of organic biomarkers in the Bajada de Jagüel section (Woelders et al., 2017). With a maximum burial temperature of $25^{\circ} \mathrm{C}$ during recrystallization, the burial depth of the late Maastrichtian strata in the Neuquèn Basin is likely to be very shallow and at the very maximum no more than $500 \mathrm{~m}$ (Klein et al., 1999; Dale et al., 2014).

\subsubsection{Implications for sampling strategy}

Contrary to what may be expected, the incorporation of vesicular calcite into the stable isotope samples of M6 (Figs. 2 and 5) is not always reflected by elevated $\mathrm{Mn}$ and $\mathrm{Fe}$ concentrations in the $\mu \mathrm{XRF}$ line scans. This could suggest that trace element signatures in vesicular calcite close to the hinge are less affected by the leaching of reducing pore waters than in the rest of the shell. Alternatively, it is likely that the $2 \mathrm{~mm}$ wide sampling track for stable isotope measurements contains more vesicular calcite than the $25 \mu \mathrm{m}$ wide XRF line. This shows that the wide sampling track needed to sample for stable isotope analysis at high spatial resolution ( $100 \mu \mathrm{m}$ in the direction of growth) increases the chance of incorporating vesicular calcite, particularly in samples further away from the hinge line and in shells where vesicular calcite layers penetrate close to the hinge line (e.g. M4 and M11; see Figs. 2, 3 and 6d). This illustrates a disadvantage of the abrasion-style microdrilling method applied in this study for spatially heterogeneous bivalves, and shows that thorough screening for diagenesis by CL microscopy and $\mu \mathrm{XRF}$ mapping is essential to correctly interpret the stable isotope results.

In summary, shells M6 and M11 are characterized by elevated $\mathrm{Fe}$ and $\mathrm{Mn}$ concentrations in the shell hinge line, signifying that these specimens contain larger amounts of recrystallized vesicular calcite in their shell hinge. Specimen M4 shows lower $\mathrm{Fe}$ and $\mathrm{Mn}$ concentrations in the shell hinge, but low stable isotope ratios show that several microdrilled samples contain diagenetically altered vesicular calcite. Stable carbon and oxygen isotope ratios in shells M4, M6 and M11 all show a significant positive relationship, while such a relationship is absent in M0. As a result, of the four specimens investigated, specimen M0 is considered to represent the best preserved specimen, most likely providing the most reliable results in terms of palaeoenvironmental reconstruction. Coloured vertical bars in Fig. 5 illustrate parts of the shell records that were considered altered based on one or
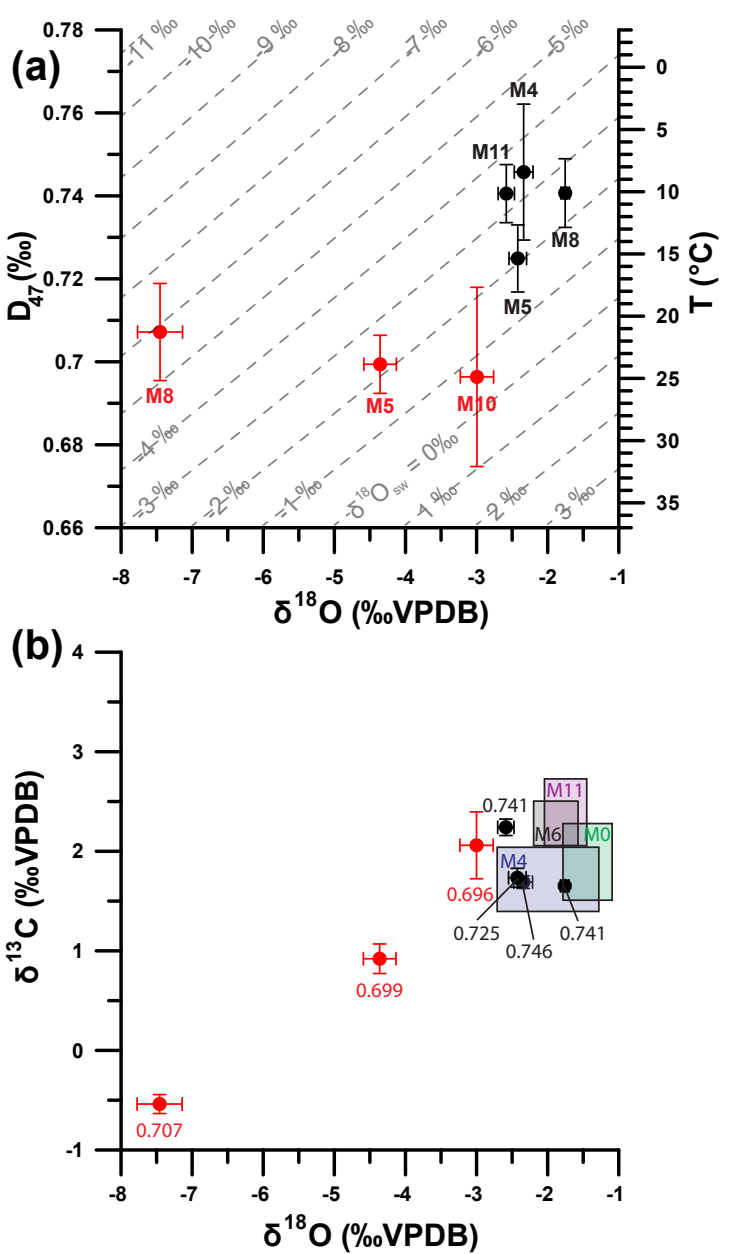

Figure 7. Cross plots of clumped isotope results. (a) $\Delta_{47}$ vs. $\delta^{18} \mathrm{O}$ from clumped isotope measurements on all seven shells. Red dots and error bars represent measurements of samples from the ventral margin of the shells, while black dots and error bars indicate results from dense, foliated calcite from the hinge of the shells. Dashed lines illustrate the $\delta^{18} \mathrm{O}$ values of seawater that correspond to the combination of $\Delta_{47}$ and $\delta^{18} \mathrm{O}$ values in the graph. (b) $\delta^{13} \mathrm{C}$ vs. $\delta^{18} \mathrm{O}$ from clumped isotope measurements on all shells. Symbols as in (a). Numbers next to the dots indicate $\Delta_{47}$ values measured in the same samples. Coloured rectangles indicate the range of pristine stable isotope values measured in high-resolution transects through the hinges of shells M0, M4, M6 and M11.

more of the criteria described above: (1) bright luminescence in CL microscopy; (2) elevated (>800 $\mu \mathrm{g} \mathrm{g}^{-1}$ ) Fe and/or Mn concentrations; (3) elevated $\mathrm{Si}(>0.5 \mathrm{~m} / \mathrm{m} \%)$ and reduced $\mathrm{Ca}$ $(<38 \mathrm{~m} / \mathrm{m} \%)$ concentrations; (4) decreased stable isotope ratios $\left(\delta^{18} \mathrm{O}<-3 \%\right.$ and $\delta^{13} \mathrm{C}<1.5 \%$ ) 


\subsection{Periodic variations}

\subsubsection{Shell chronology}

While earlier studies have been successful in determining the chronology of geochemical records from Quaternary fossil bivalves (e.g. Scourse et al., 2006; Marali and Schöne, 2014), attempts at palaeoseasonality reconstructions based on more ancient shells have shown that this is not straightforward (Dettmann and Lohmann, 1993; Bougeois et al., 2014; de Winter and Claeys, 2016; de Winter et al., 2017a). In this study, quasi-periodic variations in stable oxygen isotopes, $\mathrm{Sr} / \mathrm{Ca}$ ratios and $\mathrm{Mg} / \mathrm{Ca}$ ratios seem to represent seasonal cycles in shell growth (Fig. 5), but on closer inspection it is difficult to find consistent phase relationships between these records through all four shells. The best-preserved record (M0) was tentatively subdivided into annual cycles based on $\mathrm{Sr} / \mathrm{Ca}$ and $\delta^{18} \mathrm{O}$ seasonality. Figure 8 shows a stack of the trace element records created based on these subdivisions. Similar year stacks of the other three shells yielded different phase relationships between proxies (SI8 in the Supplement). These differences are likely explained by the incorporation of diagenetically altered vesicular calcite in some of the microdrilled samples, resulting in significantly lighter $\delta^{18} \mathrm{O}$ and $\delta^{13} \mathrm{C}$ values. The record of shell M4 (Fig. 5) clearly illustrates how diagenesis can preferentially influence one season over the other and result in a change of the phase relationship between proxies in the shell. Since incorporation of lobes of vesicular calcite into the shell hinge seems to be paced to the seasonal cycle, it is difficult to disentangle patterns of diagenetic alteration from seasonal patterns. Such preferential incorporation of vesicular calcite into the hinge during one season can occur when the bivalve experiences more physiological stress in that season (Müller, 1970). Indeed, even when diagenetically altered parts of these records (according to the threshold of $800 \mu \mathrm{g} \mathrm{g}^{-1}$ for Fe and $\mathrm{Mn}$ and $-3 \%$ o for $\delta^{18} \mathrm{O}$ ) are excluded, seasonal patterns in year stacks of shells M4, M6 and M11 do not fully agree with those in the better preserved M0 shell, showing that poorer preservation prevents the establishment of a reliable chronology for these shells. That said, records from shells M4, M6 and M11 should not be dismissed, as variation in the geochemical proxies measured in pristine parts of these shells could still yield valuable information about the extent of seasonality during their growth, even though phase relationships are blurred by diagenetic overprinting. Moreover, since the exact stratigraphic level of the shells is not fully constrained, small differences in expression of the proxies due to changes in environment between their lifetimes cannot be fully excluded. The fact that microdrill and $\mu$ XRF tracks in these shells were not exactly the same further complicates the establishment of consistent phase relationships between geochemical records in the shells. For example, stable isotope samples were more severely laterally averaged $(2 \mathrm{~mm}$ wide track compared to $25 \mu \mathrm{m}$ wide $\mu \mathrm{XRF}$ transect), and had to be rescaled to the length of XRF records before being plotted in Fig. 5 (see Sect. 4.5).

\subsubsection{Phase relationships}

The year stack of the well-preserved specimen M0 (Fig. 8) shows that the $\delta^{18} \mathrm{O}, \delta^{13} \mathrm{C}$ and $\mathrm{Sr} / \mathrm{Ca}$ records exhibit a sinusoidal pattern with one peak per year. In contrast, records of $\mathrm{Zn} / \mathrm{Ca}, \mathrm{S} / \mathrm{Ca}$ and $\mathrm{Mg} / \mathrm{Ca}$ show two peaks in each year. Comparing these observations with the records in Fig. 5 shows that the same seems to be true for the pristine parts of the other three shells. In addition, the M0 year stack shows that maxima in $\delta^{13} \mathrm{C}$ ratios coincide with minima in $\mathrm{Sr} / \mathrm{Ca}$ and $\mathrm{Zn} / \mathrm{Ca}$ and that minima in $\delta^{13} \mathrm{C}$ ratios shortly follow minima in $\delta^{18} \mathrm{O}$. $\mathrm{Zn} / \mathrm{Ca}$ and $\mathrm{S} / \mathrm{Ca}$ records show an antiphase relationship, and the $\mathrm{Mg} / \mathrm{Ca}$ record has one minimum that coincides with a minimum in $\delta^{18} \mathrm{O}$ ratios and another offset by half a cycle. Yet, since only one of the shells measured in this study (M0) showed good enough preservation for a discussion of phase relationships between records, care must be taken in extrapolating the conclusions drawn from the year stack of this single shell.

\subsection{Interpreting geochemical records in Pycnodonte vesicularis}

\subsubsection{Comparison with other taxa}

Carbon isotope values found in this study are higher than in oysters living in modern coastal temperate environments (Surge et al., 2001; Ullmann et al., 2010), but more similar to oysters living in warmer, high-salinity or tropical settings (Klein et al., 1996a; Surge and Lohmann, 2008; Titschack et al., 2010). Oxygen isotope ratios are generally lower than modern coastal mid-latitude bivalves (Klein et al., 1996b; Ullmann et al., 2010) and in better agreement with warmer, low-latitude studies (Lécuyer et al., 2004) and other Cretaceous bivalves (Steuber, 1999). This is in agreement with reconstructions of $\delta^{18} \mathrm{O}$ ratios in Late Cretaceous oceans that were $\sim 1 \%$ o lower compared to the present-day ocean due to the absence of extensive polar ice sheets (e.g. Hay, 2008), and also with the warmer palaeoenvironmental setting inferred for the Late Cretaceous of Neuquén Basin, based on TEX $_{86}$ palaeothermometry (Woelders et al., 2017). However, the clumped isotope thermometry results of this study suggests rather cooler temperatures. In order to properly interpret geochemical records from $P$. vesicularis, it is important to compare the results of this study with those from closely related bivalves. Although the genus Pycnodonte has no living members, two sister taxa in the subfamily Pycnodonteinae (Stenzel, 1956) contain extant members: Hyotissa and Neopycnodonte (Stenzel, 1971). 


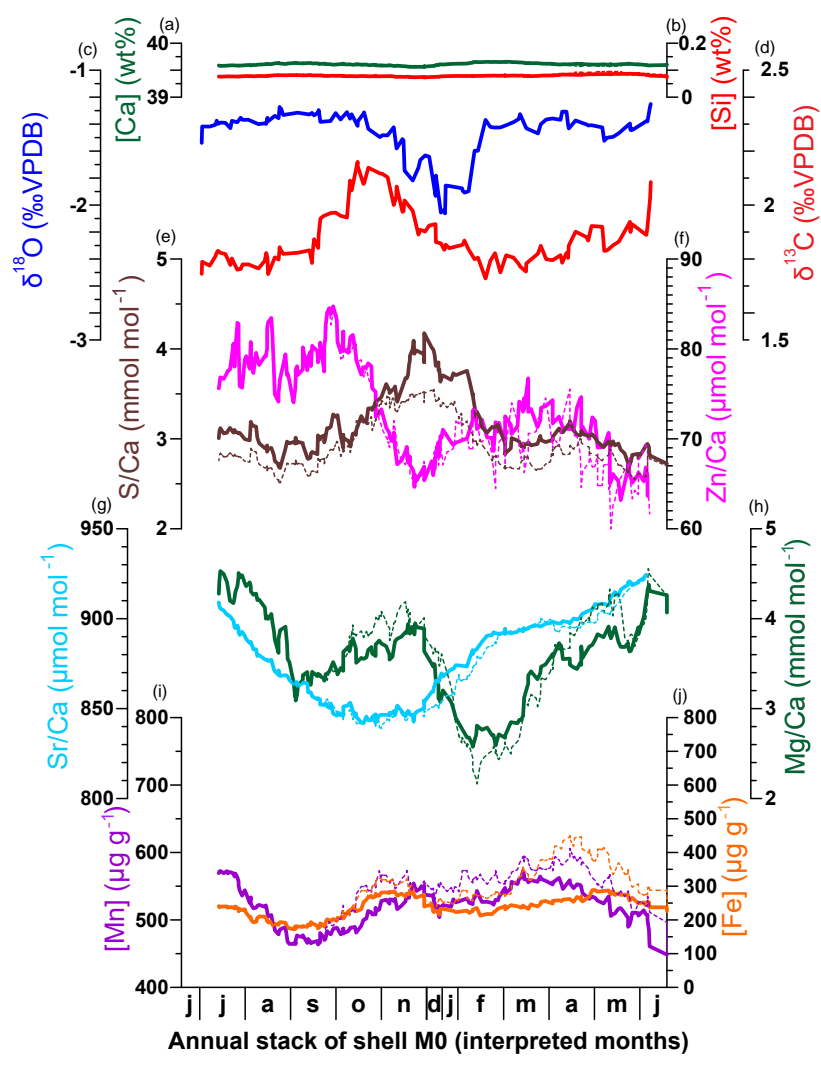

Figure 8. Stack of proxy records for shell M0 made according to a tentative interpretation of annual cyclicity based on $\delta^{18} \mathrm{O}$ and $\mathrm{Sr} / \mathrm{Ca}$ ratios in Fig. 5. Solid lines indicate annual stacks excluding diagenetically altered samples while dashed lines include all measured samples to show the effect of diagenesis. From top to bottom, stacks of $\mathrm{Ca}$ (green), $\mathrm{Si}$ (red), $\delta^{13} \mathrm{C}$ (red), $\delta^{18} \mathrm{O}$ (blue), $\mathrm{S} / \mathrm{Ca}$ ratios (brown), $\mathrm{Zn} / \mathrm{Ca}$ ratios (purple), $\mathrm{Sr} / \mathrm{Ca}$ ratios (light blue), $\mathrm{Mg} / \mathrm{Ca}$ (green), Mn (purple) and Fe (orange) records are shown. Subdivisions of the stack into months are based on an interpretation of the phase relationship between the proxies in terms of palaeoenvironmental seasonality. Note that summer months (December and January) are underrepresented in the record due to the interpreted decrease or cessation of shell growth.

\subsubsection{Hyotissa hyotis (Linnaeus, 1758)}

The microstructure of Hyotissa hyotis is similar to that of $P$. vesicularis, with porous vesicular phases alternating with dense, foliated calcite layers. A specimen of Hyotissa hyotis in the northern Red Sea was subject to a stable isotope study by Titschack et al. (2010). Contrary to findings by Nestler (1965), but similar to H. hyotis (Titschack et al., 2010) and modern oysters like Crassostrea virginica (Surge and Lohmann, 2008) and Crassostrea gigas (Ullmann et al., 2010), seasonal variations in $\delta^{18} \mathrm{O}$ and $\delta^{13} \mathrm{C}$ in $P$. vesicularis were found to be independent of shell microstructure (foliated vs. vesicular calcite). This shows that the isotopically light signal of the vesicular calcite in the records of M4, M6 and M11 was caused by recrystallization, disturbing the seasonality signal in their stable isotope records, hampering the interpretation of shell chronology (see Sect. 6.2.1). Stable carbon isotope ratios in $P$. vesicularis resemble those measured in $H$. hyotis in terms of absolute values and seasonal amplitude. In principle, the $\delta^{13} \mathrm{C}$ of shell carbonate is controlled by the $\delta^{13} \mathrm{C}$ value of the dissolved inorganic carbon (DIC) of the organism's extrapallial fluid (EPF), from which the shell is precipitated (Kirby, 2000). In marine bivalves, the $\delta^{13} \mathrm{C}$ of the EPF is controlled by the $\delta^{13} \mathrm{C}$ of ambient seawater, the carbonate ion pump, $\mathrm{pH}$, food availability, growth, valve gape/closure intervals and seasonal changes in metabolic rate (Romanek et al., 1992; McConnaughey et al., 1997; Kirby et al., 1998; Owen et al., 2002; Geist et al., 2005; McConnaughey and Gillikin, 2008; Lartaud et al., 2010b). The variation in all these processes complicates practical interpretation of the $\delta^{13} \mathrm{C}$ signal (Lorrain et al., 2004; Omata et al., 2005). In H. hyotis, $\delta^{13} \mathrm{C}_{\text {shell }}$ is controlled by bivalve respiration, which increases during periods of enhanced planktonic food supply (Titschack et al., 2010). A phase-shifted relationship between $\delta^{18} \mathrm{O}$ and $\delta^{13} \mathrm{C}$ in $\mathrm{H}$. hyotis, similar to the phase shift observed in Fig. 8, is attributed to phase-shifted cycles in sea surface temperature and productivity. Comparison with modern $H$. hyotis therefore suggests that annual lows in $\delta^{13} \mathrm{C}$ values in P. vesicularis also indicate periods of increased food supply, such as plankton blooms.

\subsubsection{Neopycnodonte zibrowii (Videt, 2004)}

While the large bivalve Neopycnodonte zibrowii shows similar alternations in vesicular and foliated calcite as P. vesicularis, it is deep dwelling $(450-500 \mathrm{~m})$, in contrast with the shallow marine taxa $P$. vesicularis and $H$. hyotis, and has a much longer lifespan. A specimen of $N$. zibrowii (Videt, 2004) was subject of a detailed multi-proxy analysis in Wisshak et al. (2009). The shell of $N$. zibrowii is characterized by much higher $\mathrm{Mg} / \mathrm{Ca}$ and $\mathrm{S} / \mathrm{Ca}$ and lower $\mathrm{Sr} / \mathrm{Ca}$ ratios than that of $P$. vesicularis. Coincidence of peaks in $\mathrm{Mg} / \mathrm{Ca}$ and $\mathrm{S} / \mathrm{Ca}$ coinciding with minima in $\mathrm{Ca}$ and $\mathrm{Sr}$ concentrations in $N$. zibrowii can be interpreted as evidence for strong vital effects controlling trace element concentrations rather than external forcing (e.g. by temperature; Lorens and Bender, 1980; Rosenberg and Hughes, 1991). Such relationships between $\mathrm{Mg} / \mathrm{Ca}, \mathrm{S} / \mathrm{Ca}$ and $\mathrm{Sr} / \mathrm{Ca}$ are not observed in $P$. vesicularis (Figs. 5, 6 and 7). Contrary to other modern oyster studies (Surge and Lohmann, 2008; Titschack et al., 2010; Ullmann et al., 2010), Wisshak et al. (2009) report an isotopic offset between vesicular and foliated calcite. However, $\delta^{18} \mathrm{O}$ values in vesicular calcite of $N$. zibrowii are higher than in its foliated calcite, opposite that of $P$. vesicularis (Fig. 5). Similarly, a strong negative ontogenetic trend in $\delta^{13} \mathrm{C}$, which is absent in P. vesicularis and most extant oysters (Fig. 5; Surge et al., 2001; Surge and Lohmann, 2008; Ullmann et al., 2010), was observed in the juvenile part of $N$. zibrowii records. While such a juvenile trend in $\delta^{13} \mathrm{C}$ is uncommon, trends later in life have been reported for other taxa and 
are thought to be caused by increasing utilization of isotopically light metabolic carbon for shell calcification (Lorrain et al., 2004; Gillikin et al., 2007). The vast difference in geochemical records between these closely related bivalve taxa (Neopycnodonte and Pycnodonte) shows that environmental setting and mode of life (growth and metabolic rates) play a large role in governing vital effects. Geochemical records in the shell of the deep-dwelling $N$. zibrowii are clearly strongly controlled by vital effects, and both shell chemistry and environmental setting of $P$. vesicularis show much closer resemblance to H. hyotis and marine Crassostrea gigas (Surge and Lohmann, 2008; Ullmann et al., 2010) than to those of $N$. zibrowii.

\subsubsection{Timing of shell deposition and seasonality}

The $\delta^{18} \mathrm{O}$ records of $H$. hyotis are strongly correlated with both sea surface temperature (SST) and sea surface salinity (SSS; Titschak et al., 2010). The fact that $\delta^{18} \mathrm{O}$ values in shells of $H$. hyotis are higher than in P. vesicularis is likely because the former grew in an environment characterized by net evaporative conditions (Safaga Bay, Egypt). As a result, salinity and $\delta^{18} \mathrm{O}_{\text {seawater }}(+2.17 \%$ o were higher than in the Neuquén Basin (-2.8\%o). Indeed, Woelders et al. (2017) argued that the late Maastrichtian environmental setting of Bajada de Jaguël was influenced by freshwater input, based on organic-walled dinoflagellate cysts, benthic foraminifera and organic biomarker proxies. Crucially, the Neuquèn Basin is interpreted to have been characterized by a strong summer precipitation maximum, suggesting that the lowest $\delta^{18} \mathrm{O}$ values in our year stack correspond to highest summer temperatures and lowest salinities (December-January). The $\delta^{18} \mathrm{O}$ curve in our year stack is strongly asymmetrical, the $\delta^{18} \mathrm{O}$ minimum peak being truncated. Such a truncation potentially reflects slower growth or a growth stop in the summer season. We propose that while in modern oysters growth is often limited by low water temperature in the winter season (e.g. Ullmann et al., 2010, 2013), increased temperatures and low salinities in the summer season of the Late Cretaceous Neuquèn Basin have limited growth of $P$. vesicularis. The effect of a similarly co-varying SSS and SST on bivalve $\delta^{18} \mathrm{O}$ and $\delta^{13} \mathrm{C}$ has been studied in Crassostrea virginica growing under changing salinity conditions (Surge et al., 2001). However, in contrast to estuarine $C$. virginica studied by Surge et al. (2001), where both stable isotope records are in phase, the best preserved specimen in our study (M0) presents a phase-shifted relationship between $\delta^{18} \mathrm{O}$ and $\delta^{13} \mathrm{C}$. Counterintuitively, following the rationale that the lowest $\delta^{18} \mathrm{O}$ values in our record reflect that the summer precipitation maximum, the annual drop in $\delta^{13} \mathrm{C}$, corresponding to months with the highest planktonic food supply, would occur shortly after growth-limiting summer conditions (February-March).

\subsubsection{Palaeoproductivity}

The coinciding of minima in $\mathrm{Zn} / \mathrm{Ca}$ with maxima in $\mathrm{S} / \mathrm{Ca}$ and minima in $\delta^{18} \mathrm{O}$ in the well-preserved M0 specimen (Figs. 5 and 6) is in agreement with the interpretation of the seasonal palaeoproductivity cycle. $\mathrm{Zn}$ concentrations in bivalve shells drop during productivity blooms, which occur late in the summer season (February-March; Calvert and Pedersen, 1993; Jackson et al., 1993; Guo et al., 1997, de Winter et al., 2017a). Spring blooms affected the amount of bio-available $\mathrm{Zn}$ in the surface ocean and forced a drop in $\mathrm{Zn} / \mathrm{Ca}$ ratios in the shells of $P$. vesicularis (Guo et al., 2002). This explains why minima in $\mathrm{Zn} / \mathrm{Ca}$ coincide with the lowest $\delta^{18} \mathrm{O}$ values, which occur in summer and precede the minima in $\delta^{13} \mathrm{C}$ which reflect a seasonality in productivity as in $H$. hyotis. Increased freshwater input into the basin during summer, which caused the warm, low-salinity conditions observed in the $\delta^{18} \mathrm{O}$ records, could have provided the nutrients that initiated this productivity bloom.

\subsubsection{Physiological effects}

The observed anti-correlation between $\delta^{18} \mathrm{O}$ and $\mathrm{S} / \mathrm{Ca}$ in M0 suggests that $\mathrm{S} / \mathrm{Ca}$ in $P$. vesicularis responded to seasonal changes in food availability, growth or respiration rate. In other groups of bivalves $\mathrm{S} / \mathrm{Ca}$ ratios were shown to reflect periods of high metabolic rate and slow shell growth (e.g. Rosenberg and Hughes, 1991). Similarly, environmental stress, such as temperature or salinity extremes, have been linked to a decrease in growth rate and an increase in the incorporation of sulfur into the organic matrix of the bivalve shell (Lorens and Bender, 1980). Therefore, a peak in S / Ca during the summer season, when growth rate presumably decreased, is in agreement with this explanation. The observation that the amplitude of $\mathrm{S} / \mathrm{Ca}$ variations in the record of M6 increases in the part of the shell where vesicular calcite penetrates the shell hinge (Fig. 5) supports the hypothesis that these disturbances of the shell hinge indicate periods of physiological stress experienced by the bivalve (Müller, 1970). The anti-phase relationship between S / Ca with $\mathrm{Zn} / \mathrm{Ca}$ and $\delta^{13} \mathrm{C}$ minima show that the productivity blooms discussed above affected growth and metabolic rate in $P$. vesicularis.

Similarly, a decrease in $\mathrm{Sr} / \mathrm{Ca}$ ratios synchronous with the peak in $\delta^{13} \mathrm{C}$ suggests that both proxies are controlled by physiology. The interpretation that $\mathrm{Sr} / \mathrm{Ca}$ ratios are lower during the low-salinity summer season in which growth was slower is in agreement with relationships between $\mathrm{Sr} / \mathrm{Ca}$ and growth rate found in modern bivalves (e.g. Gillikin et al., 2005a; Lorrain et al., 2005). However, if $\mathrm{Sr} / \mathrm{Ca}$ is indeed controlled by growth rate, one would expect to see an ontogenetic drift of $\mathrm{Sr} / \mathrm{Ca}$ towards lower ratios as the shell extends more slowly as the animal ages. Yet, this effect is not clearly expressed by our specimens, indicating that either $P$. vesicularis did not exhibit such a decreasing trend in 
growth rate with age or that the relationship between $\mathrm{Sr} / \mathrm{Ca}$ and growth rate is not straightforward.

\subsection{Temperature proxies}

An overview of all temperature proxies used in this study is plotted in Fig. 9, illustrating the complexity of combining these different proxies in $P$. vesicularis to reconstruct palaeoseasonality. Combination of the $\delta^{18} \mathrm{O}_{\mathrm{sw}}$ values reconstructed using clumped isotope analysis with the highresolution $\delta^{18} \mathrm{O}$ records yields a sub-annual palaeotemperature reconstruction for all records. However, the variations in these records may not reflect true sub-annual temperature variations, especially since it is likely that salinity in the Neuquén Basin did not remain constant through the year (see Sect. 6.3.4). Clumped isotope temperature reconstructions are similar to present-day average annual surface water temperatures in the region $\left(\sim 10-15^{\circ} \mathrm{C}\right.$; Servicio Meteorológico Nacional, 2017), while they are below model and proxy-based SST reconstructions for the Maastrichtian midlatitudes $\left(20-25^{\circ} \mathrm{C}\right.$; e.g. Donnadieu et al., 2006; Brugger et al., 2017; O'Brien et al., 2017) and average air temperatures inferred for the Maastrichtian Neuquén Basin based on the megathermal vegetation $\left(>24^{\circ}\right.$; Barreda and Palazzesi, 2007; Palazzesi and Barreda, 2007; Barreda et al., 2012). The systematically lower clumped isotope-based temperatures can partially be explained by the fact that $\mathrm{TEX}_{86}^{H}$ is calibrated to sea surface temperatures while $P$. vesicularis lived on the sea floor, at depths of 50-75 m (Scasso et al., 2005). This means that while TEX $_{86}^{H}$ reflects SSTs, the $P$. vesicularis clumped isotope-based temperatures reflect the temperatures of the bottom waters, which must have been slightly cooler than those at the sea surface. However, this difference is likely not enough to explain the offset of $\pm 15^{\circ} \mathrm{C}$ between clumped isotope and $\mathrm{TEX}_{86}^{H}$ temperature reconstructions. Over the past years, several studies have highlighted the complexity of shallow marine $\mathrm{TEX}_{86}$ records and have shown that temperature reconstructions by this method may be biased (e.g. Jia et al., 2017). Similarly, in the compilation study of O'Brien et al. (2017), Cretaceous $\mathrm{TEX}_{86}$-based sea surface temperatures are systematically higher than planktic foraminiferal $\delta^{18} \mathrm{O}$ based temperatures. In some settings, $\mathrm{TEX}_{86}$ is shown to be biased towards summer temperatures (Schouten et al., 2013). It is possible that the same bias also applies to the Neuquen Basin TEX ${ }_{86}^{H}$ reconstructions. On the other hand, clumped isotope thermometry on P. vesicularis relies on bulk samples and yields mean value of the entire growth season of the bivalve. Since growth in $P$. vesicularis seems to have slowed or ceased during the spring and summer season (see Sects. 6.3.4 and 6.3.6), summer temperatures are likely underrepresented in the clumped isotope reconstructions, biasing them towards lower temperatures. It is therefore likely that the mean annual temperature in this setting lies in between clumped isotope thermometry and $\mathrm{TEX}_{86}^{H}$ estimates. Another source of bias for clumped isotope thermometry on bulk samples is the incorporation of diagenetically altered vesicular calcite into the shell hinge as a result of more stressful growth conditions (Müller, 1970; see Sects. 6.2.1). However, this would have biased the reconstruction towards higher temperatures, while the opposite is observed. In practice it will be difficult to avoid these lobes of vesicular calcite and small amounts are likely to be included in clumped isotope samples, leading to higher palaeotemperature reconstructions.

While several temperature calibrations exist for $\mathrm{Mg} / \mathrm{Ca}$ ratios in bivalves, the most likely candidates for temperature reconstruction based on $\mathrm{Mg} / \mathrm{Ca}$ of $P$. vesicularis are the calibrations based on other ostreid bivalves. A good candidate would be the calibration by Surge and Lohmann (2008; based on Crassostrea virginica). An alternative calibration by Mouchi et al. (2013) was based on juvenile specimens of the Pacific oyster Crassostrea gigas and is probably not suitable for application on records from gerontic specimens. The $\mathrm{Mg} / \mathrm{Ca}$ ratio of ocean water $\left(\mathrm{Mg} / \mathrm{Ca}_{\text {ocean }}\right)$ has changed drastically over geological timescales, and is thought to have been much lower in the late Maastrichtian than in the present-day ocean (1-2 compared to $5 \mathrm{~mol} \mathrm{~mol}^{-1}$ in the modern ocean; Stanley and Hardie, 1998; Coggon et al., 2010). This difference most likely influenced $\mathrm{Mg} / \mathrm{Ca}$ ratios in calcifying organisms (Lear et al., 2015), and needs to be corrected for (de Winter et al., 2017a) when applying the $\mathrm{Mg} / \mathrm{Ca}$ thermometer. With this correction, the C. virginica temperature calibration by Surge and Lohmann (2008; Fig. 9) approaches reconstructions based on the other proxies in terms of temperature seasonality, yielding sea water temperatures of $20 \pm 10^{\circ} \mathrm{C}$, slightly higher than those observed in the $\delta^{18} \mathrm{O}_{\mathrm{sw}}$-corrected $\delta^{18} \mathrm{O}$ record.

Since $\mathrm{Mg}$ / Ca ratios yield temperatures between clumped isotope and $\mathrm{TEX}_{86}^{H}$ reconstructions, it is tempting to assume that they more closely approximate mean annual temperatures than the other proxies. However, while the seasonal bias caused by growth cessations in $P$. vesicularis should affect $\mathrm{Mg} / \mathrm{Ca}$ as much as $\delta^{18} \mathrm{O}$, there are large differences $\left(>10^{\circ} \mathrm{C}\right)$ between temperature reconstructions of $\mathrm{Mg} / \mathrm{Ca}$ and $\delta^{18} \mathrm{O}$ in some parts of the records. Moreover, $\mathrm{Mg} / \mathrm{Ca}$ ratios and $\delta^{18} \mathrm{O}$ are anti-correlated in parts of the wellpreserved M0 record, suggesting that at least one of the proxies may largely be controlled by a factor other than ambient temperature. Seasonal changes in salinity cannot account for this difference between the proxies, since an unrealistic change in salinity would be required, which is not consistent with earlier palaeoenvironmental reconstructions in the Neuquén Basin (Prámparo et al. 1996; Prámparo and Papú 2006; Ravelo and Hillaire-Marcel, 2007; Woelders et al., 2017). The shift between $\mathrm{Mg} / \mathrm{Ca}$ and $\delta^{18} \mathrm{O}$ records may also be a result of the relative scaling and aligning of records measured using two different methods. Nevertheless, the uncertainties of $\mathrm{Mg} / \mathrm{Ca}$ temperature reconstructions in bivalves, together with the observed lack of temperature dependence of $\mathrm{Mg} / \mathrm{Ca}$ ratios in the closely related $N$. zibrowii shows that 


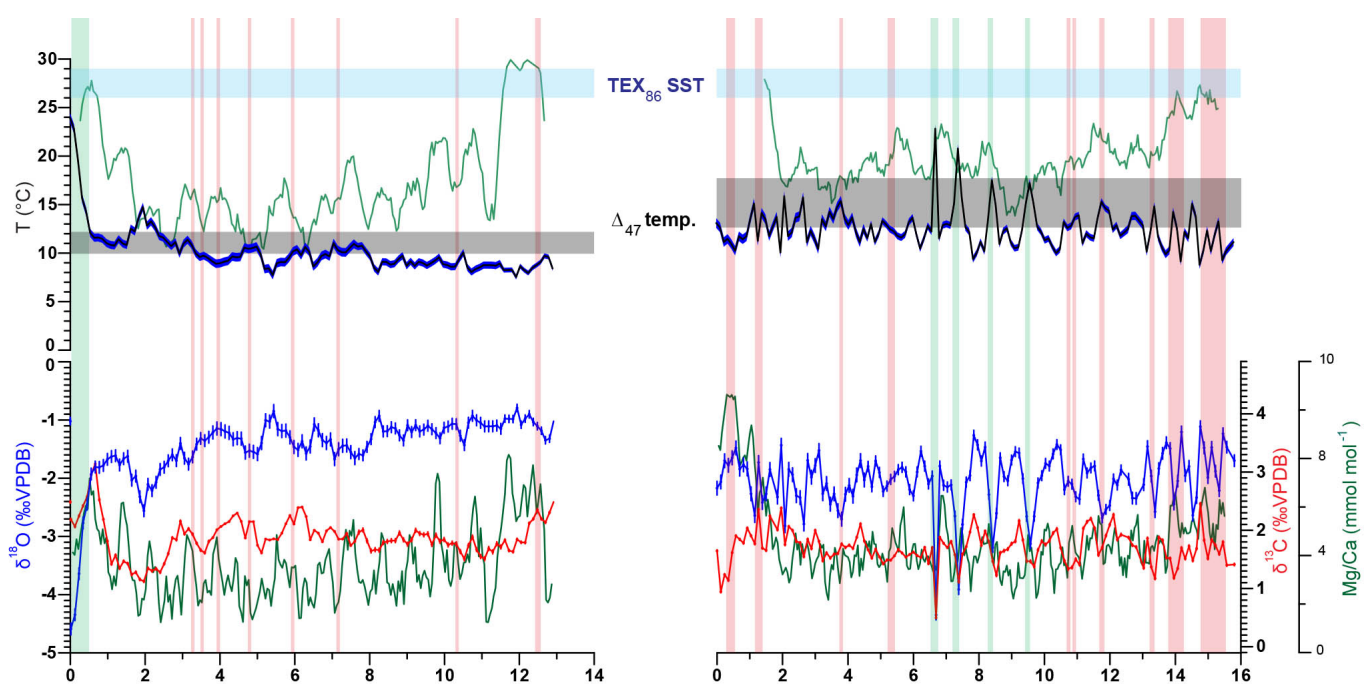

(a) MO distance along growth axis $(\mathrm{mm})$

(b) M4 distance along growth axis $(\mathrm{mm})$
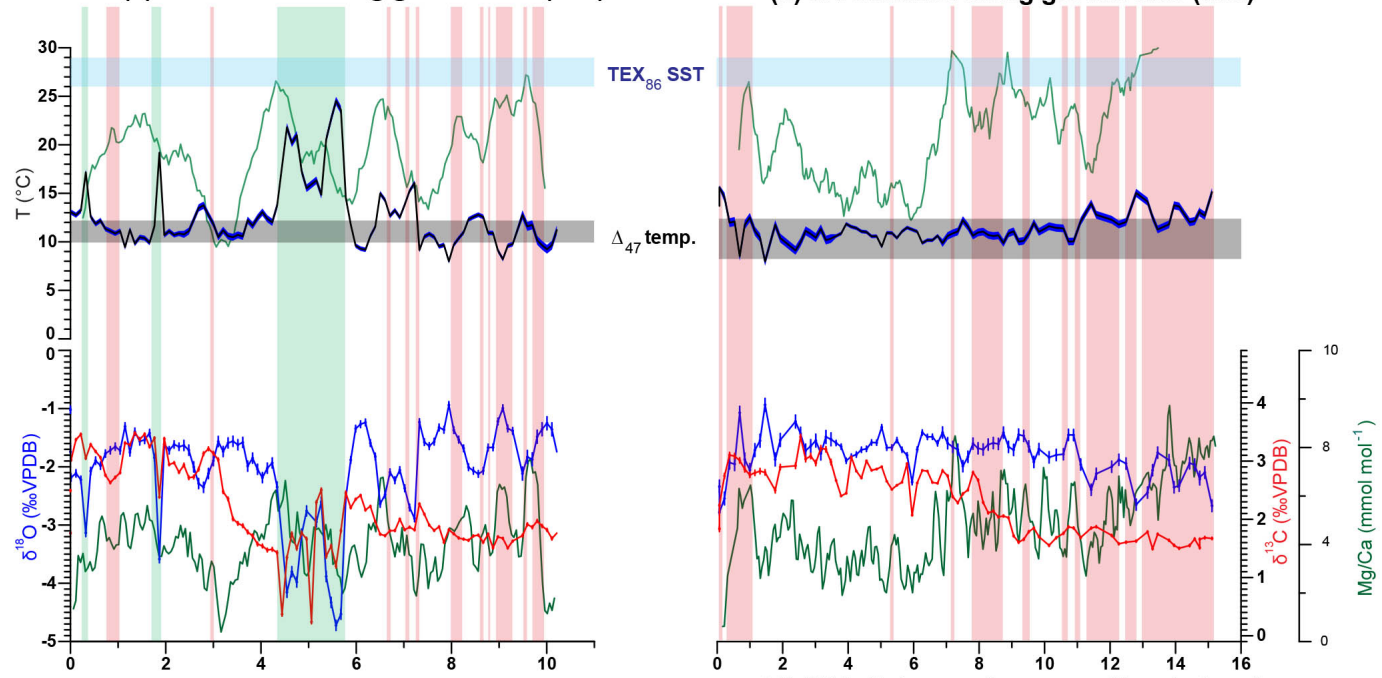

(c) M6 distance along growth axis ( $\mathbf{m m})$

(d) M11 distance along growth axis $(\mathrm{mm})$

Figure 9. Overview of stable isotope and $\mathrm{Mg} / \mathrm{Ca}$ records (bottom) as well as tentative temperature and salinity reconstructions (top) based on $\delta^{18} \mathrm{O}$ (blue) and $\mathrm{Mg} / \mathrm{Ca}$ (green), clumped isotope analysis (grey bars) and TEX $\mathrm{T}_{66}^{H}$ palaeothermometry (light blue bars). Temperatures calculated from $\delta^{18} \mathrm{O}$ records (dark blue on top) are based on the calibration by Hays and Grossman (1991) and the $\delta^{18} \mathrm{O}_{\mathrm{sw}}$ value of the clumped isotope measurements indicated in grey. $\mathrm{Mg} / \mathrm{Ca}$ temperatures (green line on top) were calculated using the calibration reported in Surge and Lohmann (2008) with a factor 3.3 correction for lower $\mathrm{Mg} / \mathrm{Ca}$ ratios in late Cretaceous ocean water. Temperatures of bulk samples of shells M4 and M11 measured using clumped isotope analysis are indicated by grey bars in graphs of M0 and M6 represent average clumped isotope temperatures of all pristine shell samples (see Table 1). Red and green vertical bars indicate intervals where vesicular calcite was incorporated in the stable isotopic measurements (see Fig. 5).

temperature reconstructions based on $\mathrm{Mg} / \mathrm{Ca}$ ratios in Pycnodonte oysters are probably not very robust.

Based on these observations, the best approach to reconstruct palaeotemperature seasonality from Pycnodonte shells would be to microsample the foliated calcite of the shells for clumped isotope analysis. This microsampling can be guided by records of conventional stable isotope ratios and trace element concentrations to ensure the sampling of material from different seasons. Via this approach, both seasonality in temperature and salinity can be reconstructed from Pycnodonte shells, and the effects of salinity and temperature on $\delta^{18} \mathrm{O}$ values can be disentangled.

\section{Conclusions and recommendations}

The multi-proxy approach applied in this work demonstrates the complexity of palaeoenvironmental reconstruction on the seasonal scale. Based on this study, several recommendations can be made for the use of $P$. vesicularis shells for palaeoseasonality and palaeoenvironment reconstruction. 
Detailed analysis of shell structure and preservation shows that shells of $P$. vesicularis, like other species of the Order Ostreoida, are characterized by two major micromorphologies of calcite, which were referred to by Carriker et al. (1980b) as "chalky" and "foliated" calcite. In the case of $P$. vesicularis, CT scanning shows that these chalky (vesicular) calcite layers are very porous (up to $65 \%$ ) and permeable for pore fluids (Fig. 4), making it prone to recrystallization (Fig. 3). The presence of bore holes, such as those made by polychaete worms, facilitates this penetration of pore fluids. Its susceptibility to diagenesis renders the vesicular calcite of pycnodontein bivalves poorly suitable for palaeoenvironmental reconstruction. Foliated calcite layers in the shell hinge of $P$. vesicularis are less affected by diagenesis and seem to preserve primary calcite, making it suitable for palaeoseasonality reconstructions. However, lobes of vesicular calcite can extend into the hinge of the shells and complicate palaeoseasonality reconstructions based on stable and clumped isotope measurements. Highly localized recrystallization and precipitation of secondary carbonates in equilibrium with these reducing pore fluids increases the concentrations of $\mathrm{Mn}$ and $\mathrm{Fe}$ (see XRF mapping and CL images in Fig. 3) and lowers stable isotope ratios. Hence, micro-analytical techniques such as cathodoluminescence microscopy, optical microscopy and $\mu \mathrm{XRF}$ mapping allow these zones of recrystallization to be avoided.

Palaeoseasonality reconstructions based on shells of $P$. vesicularis or other gryphaeid shells that contain multiple microstructures should benefit from the application of a multiproxy approach that allows the interpretation of seasonally changing environmental parameters. However, selective diagenetic overprinting, the occurrence of growth cessations and the complexity of synchronizing proxy records from multiple methods can complicate the interpretation of phase relationships between proxies. Multi-proxy analysis on one exceptionally well-preserved specimen demonstrates how the timing of seasonal deposition of the shell could be determined from the phase relationships between proxies. Stable and clumped isotope records of primary foliated calcite in the hinge of $P$. vesicularis yield a $\delta^{18} \mathrm{O}_{\text {seawater }}$ of $-2.8 \%$ indicative of seasonal freshwater input into the Neuquén Basin. Mean annual sea water temperatures were $11^{\circ} \mathrm{C}$ based on clumped isotope thermometry, which is much lower than reconstructions based on contextual $\mathrm{TEX}_{86}^{H}$ palaeothermometry $\left(27.3 \pm 2.5^{\circ} \mathrm{C}\right)$. We conclude that the $\mathrm{TEX}_{86}^{H}$ method likely overestimates mean annual temperatures in this setting, possibly representing summer surface water temperatures. Clumped isotope thermometry of bulk foliated calcite samples likely underestimates the annual mean because the warm spring and early summer season is underrepresented in the shells due to slower growth or growth cessations. A seasonality in $\delta^{18} \mathrm{O}$ of about $1 \%$ is ascribed to a combination of decreased salinity by freshwater input in the summer season and a moderate temperature seasonality. Attempts to verify the seasonality in SST by $\mathrm{Mg} / \mathrm{Ca}$ ratios of shell calcite are complicated by uncertainties about vital effects on the incorporation of $\mathrm{Mg}$ into the bivalve shell. Records of $\mathrm{Zn} / \mathrm{Ca}$, $\mathrm{S} / \mathrm{Ca}$ and $\delta^{13} \mathrm{C}$ show that the warm, low-salinity summer season is followed by a peak in productivity which influenced the chemistry of the sea water in which $P$. vesicularis lived. The reconstruction of temperature seasonality from fossil bivalve calcite is complicated by the influence of other palaeoenvironmental parameters that affect the chemistry of bivalve shells. Yet, the successful application of clumped isotope thermometry on fossil bivalve calcite in this study indicates that temperature seasonality in fossil ostreid bivalves may be constrained by the sequential analysis of foliated calcite samples using this method.

Data availability. Supplementary data are available at https://doi. org/10.1594/PANGAEA.881640.

\section{The Supplement related to this article is available online at https://doi.org/10.5194/cp-14-725-2018-supplement.}

Competing interests. The authors declare that they have no conflict of interest.

Acknowledgements. Niels J. de Winter is financed by a personal PhD fellowship from IWT Flanders (IWT700). This research was partly financed by the FOD40 Chicxulub grant obtained by Philippe Claeys and by Research Foundation Flanders (FWO) grant G.0B85.13 to Robert P. Speijer and Philippe Claeys. Johan Vellekoop is also funded by a personal research grant from FWO (grant 12Z6618N). Thanks go to the Hercules Foundation Flanders for acquisition of XRF instrumentation (grant HERC1309) and VUB Strategic Research Program for support of the AMGC research group. The authors thank Rudy Swennen from the KU Leuven for analytical support.

Edited by: Arne Winguth

Reviewed by: two anonymous referees

\section{References}

Abele, D., Brey, T., and Philipp, E.: Bivalve models of aging and the determination of molluscan lifespans, Exp. Gerontol., 44, 307315, 2009.

Aberhan, M. and Kiessling, W.: Rebuilding biodiversity of Patagonian marine molluscs after the endCretaceous mass extinction, PloS one, 9, e102629, https://doi.org/10.1371/journal.pone.0102629, 2014.

Aberhan, M., Weidemeyer, S., Kiessling, W., Scasso, R. A., and Medina, F. A.: Faunal evidence for reduced productivity and uncoordinated recovery in Southern Hemisphere CretaceousPaleogene boundary sections, Geology, 35, 227-230, 2007. 
Al-Aasm, I. S. and Veizer, J.: Diagenetic stabilization of aragonite and low-Mg calcite, I, Trace elements in rudists, J. Sediment. Res., 56, 138-152, 1986a.

Al-Aasm, I. S. and Veizer, J.: Diagenetic stabilization of aragonite and low-Mg calcite, II, Stable isotopes in rudists, J. Sediment. Res., 56, 763-770, 1986b.

Andrews, J. E., Tandon, S. K., and Dennis, P. F.: Concentration of carbon dioxide in the Late Cretaceous atmosphere, J. Geol. Soc. London, 152, 1-3, 1995.

Ayyasami, K.: Role of oysters in biostratigraphy: A case study from the Cretaceous of the Ariyalur area, southern India, Geosci. J., 10, 237-247, 2006.

Baldoni, A. M.: Palynology of the lower lefipan formation (upper cretaceous) of barranca de los perros, chubut province, Argentina, Part I, Cryptogam spores and gymnosperm pollen, Palynology, 16, 117-136, 1992.

Banner, J. L. and Hanson, G. N.: Calculation of simultaneous isotopic and trace element variations during water-rock interaction with applications to carbonate diagenesis, Geochim. Cosmochim. Ac., 54, 3123-3137, 1990.

Barbin, V.: Cathodoluminescence of carbonate shells: biochemical vs diagenetic process, in: Cathodoluminescence in Geosciences, Springer, Berlin, 303-329, 2000.

Barreda, V. and Palazzesi, L.: Patagonian vegetation turnovers during the Paleogene-early Neogene: origin of arid-adapted floras, Bot. Rev., 73, 31-50, 2007.

Barreda, V. D., Cúneo, N. R., Wilf, P., Currano, E. D., Scasso, R. A., and Brinkhuis, H.: Cretaceous/Paleogene floral turnover in Patagonia: drop in diversity, low extinction, and a Classopollis spike, Plos One, 7, e52455, https://doi.org/10.1371/journal.pone.0052455, 2012.

Berner, R.: Atmospheric carbon dioxide levels over Phanerozoic time, Science, 249, 1382-1386, 1990.

Bertels, A.: Micropaleontología y estratigrafía del lîmite CretácicoTerciario en Huantrai-co (provincia de Neuquén), Ostracoda, Parte 1: Cytherellidae, Bairdiidae, Pontocypridinae, Buntoniinae y Trachyleberidinae (pro parte), Ameghiniana, 5, 279-298, 2013.

Bieler, R., Mikkelsen, P. M., Lee, T., and Foighil, D.Ó.: Discovery of the Indo-Pacific oyster Hyotissa hyotis (Linnaeus, 1758) in the Florida Keys (Bivalvia: Gryphaeidae), Molluscan Res., 24, 149159, 2004.

Bougeois, L., De Rafélis, M., Reichart, G.-J., De Nooijer, L. J., Nicollin, F., and Dupont-Nivet, G.: A high resolution study of trace elements and stable isotopes in oyster shells to estimate Central Asian Middle Eocene seasonality, Chem. Geol., 363, 200-212, 2014.

Brand, U. and Veizer, J.: Chemical diagenesis of a multicomponent carbonate system-1: Trace elements, J. Sediment. Res., 50, 1219-1236, 1980.

Brezina, S. S., Romero, M. V., Casadío, S., and Bremec, C.: Boring Polychaetes Associated with Pycnodonte (Phygraea) vesicularis (Lamarck) from the Upper Cretaceous of Patagonia, A Case of Commensalism, Ameghiniana, 51, 129-140, 2014.

Brugger, J., Feulner, G., and Petri, S.: Baby, it's cold outside: Climate model simulations of the effects of the asteroid impact at the end of the Cretaceous: Chicxulub impact cooling, Geophys. Res. Lett., 44, 419-427, https://doi.org/10.1002/2016GL072241, 2017
Butler, P. G., Wanamaker, A. D., Scourse, J. D., Richardson, C. A., and Reynolds, D. J.: Variability of marine climate on the North Icelandic Shelf in a 1357-year proxy archive based on growth increments in the bivalve Arctica islandica, Palaeogeogr. Palaeocl., 373, 141-151, 2013.

Calmano, W., Hong, J., and Förstner, U.: Binding and mobilization of heavy metals in contaminated sediments affected by $\mathrm{pH}$ and redox potential, Water Sci. Technol., 28, 223-235, 1993.

Calvert, S. E. and Pedersen, T. F.: Geochemistry of Recent oxic and anoxic marine sediments: Implications for the geological record, Marine Geology, Marine Sediments, Burial, Pore Water Chemistry, Microbiology and Diagenesis, Mar. Geol., 113, 6788, https://doi.org/10.1016/0025-3227(93)90150-T, 1993.

Carré, M., Bentaleb, I., Blamart, D., Ogle, N., Cardenas, F., Zevallos, S., Kalin, R. M., Ortlieb, L., and Fontugne, M.: Stable isotopes and sclerochronology of the bivalve Mesodesma donacium: potential application to Peruvian paleoceanographic reconstructions, Palaeogeogr. Palaeocl., 228, 4-25, 2005.

Carriker, M. R., Palmer, R. E., Sick, L. V., and Johnson, C. C.: Interaction of mineral elements in sea water and shell of oysters (Crassostrea virginica (Gmelin)) cultured in controlled and natural systems, J. Exp. Mar. Biol. Ecol., 46, 279-296, 1980a.

Carriker, M. R., Palmer, R. E., and Prezant, R. S.: Ultrastructural morphogenesis of prodissoconch and early dissoconch valves of the oyster Crassostrea virginica, College of Marine Studies, University of Delaware, 1980b.

Chauvaud, L., Lorrain, A., Dunbar, R. B., Paulet, Y.-M., Thouzeau, G., Jean, F., Guarini, J.-M., and Mucciarone, D.: Shell of the Great Scallop Pecten maximus as a high-frequency archive of paleoenvironmental changes, Geochem. Geophy. Geosy., 6, Q08001, https://doi.org/10.1029/2004GC000890, 2005.

Chinzei, K. and Seilacher, A.: Remote Biomineralization I: Fill skeletons in vesicular oyster shells (with 7 figures in the text), Neues Jahrb. Geol. P.-A., 190, 349-362, 1993.

Coggon, R. M., Teagle, D. A., Smith-Duque, C. E., Alt, J. C., and Cooper, M. J.: Reconstructing past seawater $\mathrm{Mg} / \mathrm{Ca}$ and $\mathrm{Sr} / \mathrm{Ca}$ from mid-ocean ridge flank calcium carbonate veins, Science, 327, 1114-1117, 2010.

Crippa, G., Angiolini, L., Bottini, C., Erba, E., Felletti, F., Frigerio, C., Hennissen, J. A. I., Leng, M. J., Petrizzo, M. R., and Raffi, I.: Seasonality fluctuations recorded in fossil bivalves during the early Pleistocene: implications for climate change, Palaeogeogr. Palaeocl., 446, 234-251, 2016.

Daëron, M., Blamart, D., Peral, M., and Affek, H. P.: Absolute isotopic abundance ratios and the accuracy of $\Delta_{47}$ measurements, Chem. Geol., 442, 83-96, 2016.

Dale, A., John, C. M., Mozley, P. S., Smalley, P. C., and Muggeridge, A. H.: Time-capsule concretions: unlocking burial diagenetic processes in the Mancos Shale using carbonate clumped isotopes, Earth Planet. Sc. Lett., 394, 30-37, 2014.

de Winter, N. J. and Claeys, P.: Micro X-ray fluorescence ( $\mu$ XRF) line scanning on Cretaceous rudist bivalves: A new method for reproducible trace element profiles in bivalve calcite, Sedimentology, 64, 231-251, https://doi.org/10.1111/sed.12299, 2016.

de Winter, N. J., Zeeden, C., and Hilgen, F. J.: Low-latitude climate variability in the Heinrich frequency band of the Late Cretaceous greenhouse world, Clim. Past, 10, 1001-1015, https://doi.org/10.5194/cp-10-1001-2014, 2014. 
de Winter, N. J., Goderis, S., Dehairs, F., Jagt, J. W. M., Fraaije, R. H. B., Van Malderen, S. J. M., Vanhaecke, F., and Claeys, P.: Tropical seasonality in the late Campanian (Late Cretaceous): Comparison between multiproxy records from three bivalve taxa from Oman, Palaeogeogr. Palaeocl., 485, 740-760, https://doi.org/10.1016/j.palaeo.2017.07.031, 2017a.

de Winter, N. J., Sinnesael, M., Makarona, C., Vansteenberge, S., and Claeys, P.: Trace element analyses of carbonates using portable and micro-X-ray fluorescence: Performance and optimization of measurement parameters and strategies, J. Anal. Atom. Spectrom., 32, 1211-1224, 2017b.

de Winter, N. J., Vellekoop, J., Vorsselmans, R., Golreihan, A., Soete, J., Petersen, S. V., Meyer, K. W., Casadio, S., Speijer, R. P., and Claeys, P.: An assessment of latest Cretaceous Pycnodonte vesicularis (Lamarck, 1806) shells as records for palaeoseasonality: A multi-proxy investigation, PANGAEA, available at: https: //doi.org/10.1594/PANGAEA.881640, Supplement to: de Winter, N. J. et al.: An assessment of latest Cretaceous Pycnodonte vesicularis (Lamarck, 1806) shells as records for palaeoseasonality: A multi-proxy investigation, Clim. Past Discuss., 2017c.

Defliese, W. F., Hren, M. T., and Lohmann, K. C.: Compositional and temperature effects of phosphoric acid fractionation on $\Delta_{47}$ analysis and implications for discrepant calibrations, Chem. Geol., 396, 51-60, 2015.

Dettman, D. L. and Lohmann, K. C.: Oxygen isotope evidence for high-altitude snow in the Laramide Rocky Mountains of North America during the Late Cretaceous and Paleogene, Geology 28, 243-246, https://doi.org/10.1130/00917613(2000)28<243:OIEFHS>2.0.CO;2, 2000.

Dettman, D. L., Kohn, M. J., Quade, J., Ryerson, F. J., Ojha, T. P., and Hamidullah, S.: Seasonal stable isotope evidence for a strong Asian monsoon throughout the past $10.7 \mathrm{Myr}$, Geology, 29, 3134, 2001.

Dettman, D. L. and Lohmann, K. C.: Seasonal Change in Paleogene Surface Water $\delta^{18} \mathrm{O}$ : Fresh-Water Bivalves of Western North America, in: Climate Change in Continental Isotopic Records, edited by: Swart, P. K., Lohmann, K. C., Mckenzie, J., and Savin, S., https://doi.org/10.1029/GM078p0153, 2013.

Dlugokencky, E.: Tans P., NOAA/ESRL, available at: www.esrl. noaa.gov/gmd/ccgg/trends/, last access 31 January 2017.

Dodd, J. R. and Crisp, E. L.: Non-linear variation with salinity of $\mathrm{Sr} / \mathrm{Ca}$ and $\mathrm{Mg} / \mathrm{Ca}$ ratios in water and aragonitic bivalve shells and implications for paleosalinity studies, Palaeogeogr. Palaeocl., 38, 45-56, 1982.

Donnadieu, Y., Pierrehumbert, R., Jacob, R., and Fluteau, F.: Modelling the primary control of paleogeography on Cretaceous climate, Earth Planet. Sc. Lett., 248, 426-437, https://doi.org/10.1016/j.epsl.2006.06.007, 2006

Dreier, A., Loh, W., Blumenberg, M., Thiel, V., Hause-Reitner, D., and Hoppert, M.: The isotopic biosignatures of photo-vs. thiotrophic bivalves: are they preserved in fossil shells, Geobiology, 12, 406-423, 2014.

Duinker, J. C., Nolting, R. F., and Michel, D.: Effects of salinity, pH and redox conditions on the behaviour of $\mathrm{Cd}, \mathrm{Zn}, \mathrm{Ni}$ and $\mathrm{Mn}$ in the Scheldt estuary, Thalassia Jugos1., 18, 191-202, 1982.

Dunbar, R. B. and Wefer, G.: Stable isotope fractionation in benthic foraminifera from the Peruvian continental margin, Mar. Geol., 59, 215-225, 1984.
Ekart, D. D., Cerling, T. E., Montanez, I. P., and Tabor, N. J.: A 400 million year carbon isotope record of pedogenic carbonate: implications for paleoatmospheric carbon dioxide, Am. J. Sci., 299, 805-827, 1999.

Elderfield, H. and Ganssen, G.: Past temperature and $\delta^{18} \mathrm{O}$ of surface ocean waters inferred from foraminiferal $\mathrm{Mg} / \mathrm{Ca}$ ratios, Nature, 405, 442-445, 2000.

Elliot, M., Welsh, K., Chilcott, C., McCulloch, M., Chappell, J., and Ayling, B.: Profiles of trace elements and stable isotopes derived from giant long-lived Tridacna gigas bivalves: potential applications in paleoclimate studies, Palaeogeogr. Palaeocl., 280, 132142, 2009.

Folk, R. L. and Land, L. S.: Mg / Ca ratio and salinity: two controls over crystallization of dolomite, AAPG Bull., 59, 60-68, 1975.

Fossilworks.org: Pycnodonte genus, age range and distribution, last access: 14 February 2017.

Freitas, P., Clarke, L. J., Kennedy, H., Richardson, C., and Abrantes, F.: $\mathrm{Mg} / \mathrm{Ca}, \mathrm{Sr} / \mathrm{Ca}$, and stable-isotope $\left(\delta^{18} \mathrm{O}\right.$ and $\left.\delta^{13} \mathrm{C}\right)$ ratio profiles from the fan mussel Pinna nobilis: Seasonal records and temperature relationships: Pinna Nobilis RATIO PROFILES, Geochem. Geophy. Geosy., 6, Q04D14, https://doi.org/10.1029/2004GC000872, 2005.

Freitas, P. S., Clarke, L. J., Kennedy, H., Richardson, C. A., and Abrantes, F.: Environmental and biological controls on elemental $(\mathrm{Mg} / \mathrm{Ca}, \mathrm{Sr} / \mathrm{Ca}$ and $\mathrm{Mn} / \mathrm{Ca})$ ratios in shells of the king scallop Pecten maximus, Geochim. Cosmochim. Ac., 70, 51195133, https://doi.org/10.1016/j.gca.2006.07.029, 2006.

Freitas, P. S., Clarke, L. J., Kennedy, H. A., and Richardson, C. A.: Inter- and intra-specimen variability masks reliable temperature control on shell $\mathrm{Mg}$ / Ca ratios in laboratory- and field-cultured Mytilus edulis and Pecten maximus (bivalvia), Biogeosciences, 5, 1245-1258, https://doi.org/10.5194/bg-5-1245-2008, 2008.

Friedrich, O., Norris, R. D., and Erbacher, J.: Evolution of middle to Late Cretaceous oceans - a 55 my record of Earth's temperature and carbon cycle, Geology, 40, 107-110, 2012.

Geist, J., Auerswald, K., and Boom, A.: Stable carbon isotopes in freshwater mussel shells: Environmental record or marker for metabolic activity, Geochim. Cosmochim. Ac., 69, 3545-3554, 2005.

Gillikin, D. P., De Ridder, F., Ulens, H., Elskens, M., Keppens, E., Baeyens, W., and Dehairs, F.: Assessing the reproducibility and reliability of estuarine bivalve shells (Saxidomus giganteus) for sea surface temperature reconstruction: implications for paleoclimate studies, Palaeogeography, Palaeogeogr. Palaeocl., 228, 70-85, 2005a.

Gillikin, D. P., Lorrain, A., Navez, J., Taylor, J. W., André, L., Keppens, E., Baeyens, W., and Dehairs, F.: Strong biological controls on $\mathrm{Sr} / \mathrm{Ca}$ ratios in aragonitic marine bivalve shells, Geochem. Geophy. Geosy., 6, Q05009, https://doi.org/10.1029/2004GC000874, 2005b.

Gillikin, D. P., Lorrain, A., Bouillon, S., Willenz, P., and Dehairs, F.: Stable carbon isotopic composition of Mytilus edulis shells: relation to metabolism, salinity, $\delta^{13} \mathrm{C}_{\mathrm{DIC}}$ and phytoplankton, Org. Geochem., 37, 1371-1382, 2006.

Gillikin, D. P., Lorrain, A., Meng, L., and Dehairs, F.: A large metabolic carbon contribution to the $\delta^{13} \mathrm{C}$ record in marine aragonitic bivalve shells, Geochim. Cosmochim. Ac., 71, 2936-2946, 2007. 
Gillikin, D. P., Lorrain, A., Paulet, Y.-M., André, L., and Dehairs, F.: Synchronous barium peaks in high-resolution profiles of calcite and aragonite marine bivalve shells, Geo-Mar. Lett., 28, 351358, 2008.

Gofas, S., Salas C., and Taviani, M.: Neopycnodonte zibrowii, available at: http://marinespecies.org/aphia.php?p=taxdetails\&id= 379789 (last access: 6 June 2018), 2009.

Goodwin, D. H., Flessa, K. W., Schöne, B. R., and Dettman, D. L.: Cross-calibration of daily growth increments, stable isotope variation, and temperature in the Gulf of California bivalve mollusk Chione cortezi: implications for paleoenvironmental analysis, Palaios, 16, 387-398, 2001.

Grossman, E. L. and Ku, T.-L.: Oxygen and carbon isotope fractionation in biogenic aragonite: temperature effects, Chem. Geol., 59, 59-74, 1986.

Guo, T., DeLaune, R. D., and Patrick, W. H.: The influence of sediment redox chemistry on chemically active forms of arsenic, cadmium, chromium, and zinc in estuarine sediment, Environ. Int., 23, 305-316, 1997.

Gutiérrez-Zugasti, I., Clarke, L. J., Garcia-Escárzaga, A., SuárezRevilla, R., and González-Morales, M.: Changes in seawater temperatures in northern Iberia during the Late Pleistocene and Early Holocene, 22nd Annual Meeting of the EAA 2016, TH513, Abstract 4, 3 September 2016.

Habermann, D.: Quantitative cathodoluminescence (CL) spectroscopy of minerals: possibilities and limitations, Miner. Petrol., 76, 247-259, 2002.

Hallmann, N., Burchell, M., Brewster, N., Martindale, A., and Schöne, B. R.: Holocene climate and seasonality of shell collection at the Dundas Islands Group, northern British Columbia, Canada - A bivalve sclerochronological approach, Palaeogeogr. Palaeocl., 373, 163-172, 2013.

Harzhauser, M., Piller, W. E., Müllegger, S., Grunert, P., and Micheels, A.: Changing seasonality patterns in Central Europe from Miocene Climate Optimum to Miocene Climate Transition deduced from the Crassostrea isotope archive, Global Planet. Change, 76, 77-84, 2011.

Hay, W. W.: Evolving ideas about the Cretaceous climate and ocean circulation, Cretaceous Res., 29, 725-753, 2008.

Hay, J. E.: Small island developing states: coastal systems, global change and sustainability, Sustain. Sci., 8, 309-326, 2013.

Hayami, I. and Kase, T.: A new cryptic species of Pycnodonte from Ryukyu Islands: a living fossil oyster, Nihon Koseibutsu Gakkai hokoku, kiji, Trans. Proc. Pal. Soc. Japan, 1070-1089, 1992.

Hays, P. D. and Grossman, E. L.: Oxygen isotopes in meteoric calcite cements as indicators of continental paleoclimate, Geology, 19, 441-444, https://doi.org/10.1130/00917613(1991)019<0441:OIIMCC>2.3.CO;2, 1991.

Huber, B. T., Norris, R. D., and MacLeod, K. G.: Deep-sea paleotemperature record of extreme warmth during the Cretaceous, Geology, 30, 123-126, https://doi.org/10.1130/00917613(2002)030<0123:DSPROE>2.0.CO;2, 2002.

Hunter, S. J., Valdes, P. J., Haywood, A. M., and Markwick, P. J.: Modelling Maastrichtian climate: investigating the role of geography, atmospheric $\mathrm{CO}_{2}$ and vegetation, Clim. Past Discuss., 4, 981-1019, https://doi.org/10.5194/cpd-4-981-2008, 2008.

Huntington, K. W., Budd, D. A., Wernicke, B. P., and Eiler, J. M.: Use of clumped-isotope thermometry to constrain the crystal- lization temperature of diagenetic calcite, J. Sediment. Res., 81, 656-669, 2011.

Iglesias, A., Wilf, P., Johnson, K. R., Zamuner, A. B., Cúneo, N. R., Matheos, S. D., and Singer, B. S.: A Paleocene lowland macroflora from Patagonia reveals significantly greater richness than North American analogs, Geology, 35, 947-950, 2007.

IPCC: Climate Change 2014: Synthesis Report, Contribution of Working Groups I, II and III to the Fifth Assessment Report of the Intergovernmental Panel on Climate Change [Core Writing Team, Pachauri, R. K. and Meyer, L. A.], IPCC, Geneva, Switzerland, 151 pp., 2014.

Jackson, L. J., Kalff, J., and Rasnnussen, J. B.: Sediment pH and redox potential affect the bioavailability of $\mathrm{Al}, \mathrm{Cu}, \mathrm{Fe}, \mathrm{Mn}$, and $\mathrm{Zn}$ to rooted aquatic macrophytes, Can. J. Fish Aquat. Sci., 50, 143-148, 1993.

Jia, G., Wang, X., Guo, W., and Dong, L.: Seasonal distribution of archaeal lipids in surface water and its constraint on their sources and the $\mathrm{TEX}_{86}$ temperature proxy in sediments of the South China Sea, J. Geophys. Res.-Biogeo., 122, 592-606, https://doi.org/10.1002/2016JG003732, 2017.

Jones, D. S.: Annual cycle of shell growth increment formation in two continental shelf bivalves and its paleoecologic significance, Paleobiology, 6, 331-340, 1980.

Jones, D. S.: Sclerochronology: reading the record of the molluscan shell: annual growth increments in the shells of bivalve molluscs record marine climatic changes and reveal surprising longevity, Am. Sci., 71, 384-391, 1983.

Kiessling, W., Aragón, E., Scasso, R., Aberhan, M., Kriwet, J., Medina, F., and Fracchia, D.: Massive corals in Paleocene siliciclastic sediments of Chubut (Argentina), Facies, 51, 233-241, 2005.

Kirby, M. X.: Paleoecological differences between Tertiary and Quaternary Crassostrea oysters, as revealed by stable isotope sclerochronology, Palaios, 15, 132-141, 2000.

Kirby, M. X., Soniat, T. M., and Spero, H. J.: Stable isotope sclerochronology of Pleistocene and Recent oyster shells (Crassostrea virginica), Palaios, 13, 560-569, 1998.

Klein, J. S., Mozley, P., Campbell, A., and Cole, R.: Spatial distribution of carbon and oxygen isotopes in laterally extensive carbonate-cemented layers: implications for mode of growth and subsurface identification, J. Sediment. Res., 69, 184-201, 1999.

Klein, R. T., Lohmann, K. C., and Thayer, C. W.: Bivalve skeletons record sea-surface temperature and $\delta^{18} \mathrm{O}$ via $\mathrm{Mg} / \mathrm{Ca}$ and ${ }^{18} \mathrm{O} /{ }^{16} \mathrm{O}$ ratios, Geology, 24, 415-418, 1996a.

Klein, R. T., Lohmann, K. C., and Thayer, C. W.: Sr / Ca and ${ }^{13} \mathrm{C} /{ }^{12} \mathrm{C}$ ratios in skeletal calcite of Mytilus trossulus: Covariation with metabolic rate, salinity, and carbon isotopic composition of seawater, Geochim. Cosmochim. Ac., 60, 4207-4221, 1996b.

Langlet, D., Alunno-Bruscia, M., Rafélis, M., Renard, M., Roux, M., Schein, E., and Buestel, D.: Experimental and natural cathodoluminescence in the shell of Crassostrea gigas from Thau lagoon (France): ecological and environmental implications, Mar. Ecol. Prog. Ser., 317, 143-156, 2006.

Lartaud, F., De Rafélis, M., Ropert, M., Emmanuel, L., Geairon, P., and Renard, M.: Mn labelling of living oysters: artificial and natural cathodoluminescence analyses as a tool for age and growth rate determination of $C$. gigas (Thunberg, 1793) shells, Aquaculture, 300, 206-217, 2010a. 
Lartaud, F., Emmanuel, L., De Rafélis, M., Pouvreau, S., and Renard, M.: Influence of food supply on the $\delta^{13} \mathrm{C}$ signature of mollusc shells: implications for palaeoenvironmental reconstitutions, Geo-Mar. Lett., 30, 23-34, 2010 b.

Lazareth, C. E., Vander Putten, E., André, L., and Dehairs, F.: Highresolution trace element profiles in shells of the mangrove bivalve Isognomon ephippium: a record of environmental spatiotemporal variations, Estuar. Coast Shelf Sci., 57, 1103-1114, 2003.

Lear, C. H., Elderfield, H., and Wilson, P. A.: Cenozoic deep-sea temperatures and global ice volumes from $\mathrm{Mg} / \mathrm{Ca}$ in benthic foraminiferal calcite, Science, 287, 269-272, 2000.

Lear, C. H., Coxall, H. K., Foster, G. L., Lunt, D. J., Mawbey, E. M., Rosenthal, Y., Sosdian, S. M., Thomas, E., and Wilson, P. A.: Neogene ice volume and ocean temperatures: Insights from infaunal foraminiferal $\mathrm{Mg}$ / Ca paleothermometry, Paleoceanography, 30, 1437-1454, 2015.

Lécuyer, C., Reynard, B., and Martineau, F.: Stable isotope fractionation between mollusc shells and marine waters from Martinique Island, Chem. Geol., 213, 293-305, 2004.

Linnaei, C.: Systema naturae per regna tria naturae: secundum classes, ordines, genera, species, cum characteribus, differentiis, synonymis, locis., 10th Edn., Lars Salvi, Stockholm, 1758.

Lorens, R. B. and Bender, M. L.: The impact of solution chemistry on Mytilus edulis calcite and aragonite, Geochim. Cosmochim. Ac., 44, 1265-1278, 1980.

Lorrain, A., Paulet, Y.-M., Chauvaud, L., Dunbar, R., Mucciarone, D., and Fontugne, M.: $\delta^{13} \mathrm{C}$ variation in scallop shells: increasing metabolic carbon contribution with body size, Geochim. Cosmochim. Ac., 68, 3509-3519, 2004.

Lorrain, A., Gillikin, D. P., Paulet, Y.-M., Chauvaud, L., Le Mercier, A., Navez, J., and André, L.: Strong kinetic effects on $\mathrm{Sr} / \mathrm{Ca}$ ratios in the calcitic bivalve Pecten maximus, Geology, 33, 965968, 2005

Loyd, S. J., Corsetti, F. A., Eiler, J. M., and Tripati, A. K.: Determining the diagenetic conditions of concretion formation: assessing temperatures and pore waters using clumped isotopes, J. Sediment. Res., 82, 1006-1016, 2012.

MacDonald, J., Freer, A., and Cusack, M.: Alignment of crystallographic $c$-axis throughout the four distinct microstructural layers of the oyster Crassostrea gigas, Cryst. Growth Des., 10, 1243 1246, 2009.

Machel, H. G. and Burton, E. A.: Factors governing cathodoluminescence in calcite and dolomite, and their implications for studies of carbonate diagenesis, available at: http://archives.datapages.com/data/sepm_sp/sc25/Factors_ Governing_Cathodoluminescence.htm (last access: 6 June 2018), 1991.

Malumian, N. and Nanez, C.: The Late Cretaceous - Cenozoic transgressions in Patagonia and the Fuegian Andes: foraminifera, palaeoecology, and palaeogeography, Biol. J. Linn. Soc., 103, 269-288, 2011.

Marali, S. and Schöne, B. R.: Oceanographic control on shell growth of Arctica islandica (Bivalvia) in surface waters of Northeast Iceland - Implications for paleoclimate reconstructions, Palaeogeogr. Palaeocl., 420, 138-149, 2015.

Marali, S., Schöne, B. R., Mertz-Kraus, R., Griffin, S. M., Wanamaker, A. D., Matras, U., and Butler, P. G.: Ba/Ca ratios in shells of Arctica islandica - Potential environmental proxy and crossdating tool, Palaeogeogr. Palaeocl., 465, 347-361, 2017.

McConnaughey, T.: ${ }^{13} \mathrm{C}$ and ${ }^{18} \mathrm{O}$ isotopic disequilibrium in biological carbonates: II, In vitro simulation of kinetic isotope effects, Geochim. Cosmochim. Ac., 53, 163-171, 1989.

McConnaughey, T. A. and Gillikin, D. P.: Carbon isotopes in mollusk shell carbonates, Geo-Mar. Lett., 28, 287-299, 2008.

McConnaughey, T. A., Burdett, J., Whelan, J. F., and Paull, C. K.: Carbon isotopes in biological carbonates: Respiration and photosynthesis, Geochim. Cosmochim. Ac., 61, 611-622, https://doi.org/10.1016/S0016-7037(96)00361-4, 1997.

Miller, K. G., Sugarman, P. J., Browning, J. V., Kominz, M. A., Hernández, J. C., Olsson, R. K., Wright, J. D., Feigenson, M. D., and Van Sickel, W.: Late Cretaceous chronology of large, rapid sea-level changes: Glacioeustasy during the greenhouse world, Geology, 31, 585-588, 2003.

Morrison, J. M., Codispoti, L. A., Gaurin, S., Jones, B., Manghnani, V., and Zheng, Z.: Seasonal variation of hydrographic and nutrient fields during the US JGOFS Arabian Sea Process Study, Deep-Sea Res. Pt. II, 45, 2053-2101, 1998.

Mouchi, V., De Rafélis, M., Lartaud, F., Fialin, M., and Verrecchia, E.: Chemical labelling of oyster shells used for time-calibrated high-resolution $\mathrm{Mg}$ / Ca ratios: a tool for estimation of past seasonal temperature variations, Palaeogeogr. Palaeocl., 373, 66-74, 2013.

Müller, A. H.: Zur funktionellen Morphologie, Taxiologie und Ökologie von Pycnodonta (Ostreina, Lamellibranchiata), Monatsberichte der Deutschen Akademie der Wissenschaften zu Berlin, 12, 902-923, 1970.

Nestler, H.: Entwicklung und Schalenstruktur von Pycnodonte uesicularis (LAM.) und Dimyodon nilssoni (v. Hag.) aus der Oberkreide, Geologie, L4, 64-77, 1965.

O’Brien, C. L., Robinson, S. A., Pancost, R. D., Sinninghe Damsté, J. S., Schouten, S., Lunt, D. J., Alsenz, H., Bornemann, A., Bottini, C., Brassell, S. C., Farnsworth, A., Forster, A., Huber, B. T., Inglis, G. N., Jenkyns, H. C., Linnert, C., Littler, K., Markwick, P., McAnena, A., Mutterlose, J., Naafs, B. D. A., Püttmann, W., Sluijs, A., van Helmond, N. A. G. M., Vellekoop, J., Wagner, T., and Wrobel, N. E.: Cretaceous sea-surface temperature evolution: Constraints from $\mathrm{TEX}_{86}$ and planktonic foraminiferal oxygen isotopes, Earth-Sci. Rev., 172, 224-247, https://doi.org/10.1016/j.earscirev.2017.07.012, 2017.

Omata, T., Suzuki, A., Kawahat, H., and Okamoto, M.: Annual fluctuation in the stable carbon isotope ratio of coral skeletons: the relative intensities of kinetic and metabolic isotope effects, Geochim. Cosmochim. Ac., 69, 3007-3016, 2005.

Otto-Bliesner, B. L., Brady, E. C., and Shields, C.: Late Cretaceous ocean: Coupled simulations with the National Center for Atmospheric Research Climate System Model, J. Geophys. Res., 107, ACL11-1, https://doi.org/10.1029/2001JD000821, 2002.

Owen, R., Kennedy, H., and Richardson, C.: Experimental investigation into partitioning of stable isotopes between scallop (Pecten maximus) shell calcite and sea water, Palaeogeogr. Palaeocl., 185, 163-174, 2002.

Palazzesi, L. and Barreda, V.: Major vegetation trends in the Tertiary of Patagonia (Argentina): a qualitative paleoclimatic approach based on palynological evidence, Flora-Morphology, Distribution, Functional Ecology of Plants, 202, 328-337, 2007. 
Pearson, P. N., Ditchfield, P. W., Singano, J., Harcourt-Brown, K. G., Nicholas, C. J., Olsson, R. K., Shackleton, N. J., and Hall, M. A.: Warm tropical sea surface temperatures in the Late Cretaceous and Eocene epochs, Nature, 413, 481-487, 2001.

Pennington, J. T. and Chavez, F. P.: Seasonal fluctuations of temperature, salinity, nitrate, chlorophyll and primary production at station H3/M1 over 1989-1996 in Monterey Bay, California, DeepSea Res. Pt. II, 47, 947-973, 2000.

Petersen, S. V., Winkelstern, I. Z., Lohmann, K. C., and Meyer, K. W.: The effects of Porapak ${ }^{\mathrm{TM}}$ trap temperature on $\delta^{18} \mathrm{O}, \delta^{13} \mathrm{C}$, and $\Delta_{47}$ values in preparing samples for clumped isotope analysis, Rapid Commun. Mass Sp., 30, 199-208, 2016.

Pirrie, D. and Marshall, J. D.: Diagenesis of Inoceramus and Late Cretaceous paleoenvironmental geochemistry: a case study from James Ross Island, Antarctica, Palaios, 5, 336-345, 1990.

Poli J. X.: Testacea Utriusque Siciliae eorumque historia et anatome, 2, pp. 75-264, i-lxxvi, pl. 19-39, Parma, Regio Typographeio, 1795.

Prámparo, M. B., Papu, O. H., and Milana, J. P.: Estudios palinológicos del miembro inferior de la Formación Pachaco, Terciano de la provincia de San Juan, Descripciones sistemáticas, Ameghiniana, 33, 397-407, 1996.

Prámparo, M. B. and Papu, O. H.: Late Maastrichtian dinoflagellate cysts from the Cerro Butaló section, southern Mendoza province, Argentina, J. Micropalaeontol., 25, 23-33, 2006.

Pugaczewska, H.: The Upper Cretaceous Ostreidae from the Middle Vistula Region (Poland), Acta Palaeontol. Pol., 22, 187-204, 1977.

Quan, C., Sun, C., Sun, Y., and Sun, G.: High resolution estimates of paleo- $\mathrm{CO}_{2}$ levels through the Campanian (Late Cretaceous) based on Ginkgo cuticles, Cretaceous Res., 30, 424-428, 2009.

Ravelo, A. C. and Hillaire-Marcel, C.: Chapter Eighteen the use of oxygen and carbon isotopes of foraminifera in Paleoceanography, Dev. Mar. Bio., 1, 735-764, 2007.

Richardson, C. A., Peharda, M., Kennedy, H., Kennedy, P., and Onofri, V.: Age, growth rate and season of recruitment of Pinna nobilis (L) in the Croatian Adriatic determined from $\mathrm{Mg}$ : Ca and Sr: Ca shell profiles, J. Exp. Mar. Biol. Ecol., 299, 1-16, 2004.

Rimstidt, J. D., Balog, A., and Webb, J.: Distribution of trace elements between carbonate minerals and aqueous solutions, Geochim. Cosmochim. Ac., 62, 1851-1863, 1998.

Romanek, C. S., Grossman, E. L., and Morse, J. W.: Carbon isotopic fractionation in synthetic aragonite and calcite: effects of temperature and precipitation rate, Geochim. Cosmochim. Ac., 56, 419-430, 1992.

Rosenberg, G. D. and Hughes, W. W.: A metabolic model for the determination of shell composition in the bivalve mollusc, Mytilus edulis, Lethaia, 24, 83-96, 1991.

Scasso, R. A., Concheyro, A., Kiessling, W., Aberhan, M., Hecht, L., Medina, F. A., and Tagle, R.: A tsunami deposit at the Cretaceous/Paleogene boundary in the Neuquén Basin of Argentina, Cretaceous Res., 26, 283-297, 2005.

Schauer, A. J., Kelson, J., Saenger, C., and Huntington, K. W.: Choice of ${ }^{17} \mathrm{O}$ correction affects clumped isotope $\left(\Delta_{47}\right)$ values of $\mathrm{CO}_{2}$ measured with mass spectrometry, Rapid Commun. Mass Sp., 30, 2607-2616, 2016.

Schlager, W. and James, N. P.: Low-magnesian calcite limestones forming at the deep-sea floor, Tongue of the Ocean, Bahamas, Sedimentology, 25, 675-702, 1978.
Schöne, B. R., Fiebig, J., Pfeiffer, M., Gleß, R., Hickson, J., Johnson, A. L., Dreyer, W., and Oschmann, W.: Climate records from a bivalved Methuselah (Arctica islandica, Mollusca; Iceland), Palaeogeogr. Palaeocl., 228, 130-148, 2005a.

Schöne, B. R., Houk, S. D., Castro, A. D. F., Fiebig, J., Oschmann, W., Kröncke, I., Dreyer, W., and Gosselck, F.: Daily growth rates in shells of Arctica islandica: assessing sub-seasonal environmental controls on a long-lived bivalve mollusk, Palaios, 20, 7892, 2005b.

Schöne, B. R., Pfeiffer, M., Pohlmann, T., and Siegismund, F.: A seasonally resolved bottom-water temperature record for the period AD 1866-2002 based on shells of Arctica islandica (Mollusca, North Sea), Int. J. Climatol., 25, 947-962, 2005 c.

Schouten, S., Hopmans, E. C., and Damsté, J. S. S.: The organic geochemistry of glycerol dialkyl glycerol tetraether lipids: a review, Org. Geochem., 54, 19-61, 2013.

Scourse, J., Richardson, C., Forsythe, G., Harris, I., Heinemeier, J., Fraser, N., Briffa, K., and Jones, P.: First cross-matched floating chronology from the marine fossil record: data from growth lines of the long-lived bivalve mollusc Arctica islandica, Holocene, 16, 967-974, 2006.

Servicio Meteorológico Nacional, Republic of Argentina, available at: http://www.smn.gov.ar/serviciosclimaticos/?mod= turismo\&id=5\&var=buenosaires, last access: 25 September 2017.

Stanley, S. M. and Hardie, L. A.: Secular oscillations in the carbonate mineralogy of reef-building and sediment-producing organisms driven by tectonically forced shifts in seawater chemistry, Palaeogeogr. Palaeocl., 144, 3-19, 1998.

Stenzel, H. B.: Cretaceous oysters of southwestern North America, Int. Geol. Congr., Mexico City, 15-37, 1956.

Stenzel, H. B.: Oysters, University of Kansas Press and Geological Society of America, Part N, Mollusca, 1971.

Steuber, T.: Stable isotope sclerochronology of rudist bivalves: Growth rates and Late Cretaceous seasonality, Geology, 24, 315-318, https://doi.org/10.1130/00917613(1996)024<0315:SISORB>2.3.CO;2, 1996.

Steuber, T.: Isotopic and chemical intra-shell variations in low-Mg calcite of rudist bivalves (Mollusca-Hippuritacea): disequilibrium fractionations and late Cretaceous seasonality, Int. J. Earth Sci., 88, 551-570, 1999.

Steuber, T., Rauch, M., Masse, J.-P., Graaf, J., and Malkoč, M.: Low-latitude seasonality of Cretaceous temperatures in warm and cold episodes, Nature, 437, 1341-1344, 2005.

Surge, D. and Lohmann, K. C.: Evaluating $\mathrm{Mg} / \mathrm{Ca}$ ratios as a temperature proxy in the estuarine oyster, Crassostrea virginica, J. Geophys. Res., 113, 2001, https://doi.org/10.1029/2007JG000623, 2008.

Surge, D., Lohmann, K. C., and Dettman, D. L.: Controls on isotopic chemistry of the American oyster, Crassostrea virginica: implications for growth patterns, Palaeogeogr., Palaeocl., 172, 283-296, 2001.

Takesue, R. K. and van Geen, A.: Mg / Ca, Sr / Ca, and stable isotopes in modern and Holocene Protothaca staminea shells from a northern California coastal upwelling region, Geochim. Cosmochim. Ac., 68, 3845-3861, 2004.

Titschack, J., Zuschin, M., Spötl, C., and Baal, C.: The giant oyster Hyotissa hyotis from the northern Red Sea as a decadal- 
scale archive for seasonal environmental fluctuations in coral reef habitats, Coral Reefs, 29, 1061-1075, 2010.

Torsvik, T. H., Van der Voo, R., Preeden, U., Mac Niocaill, C., Steinberger, B., Doubrovine, P. V., van Hinsbergen, D. J., Domeier, M., Gaina, C., and Tohver, E.: Phanerozoic polar wander, palaeogeography and dynamics, Earth-Sci. Rev., 114, 325368,2012

Tripati, A., Zachos, J., Marincovich Jr., L., and Bice, K.: Late Paleocene Arctic coastal climate inferred from molluscan stable and radiogenic isotope ratios, Palaeogeogr. Palaeocl., 170, 101-113, https://doi.org/10.1016/S0031-0182(01)00230-9, 2001.

Ullmann, C. V., Wiechert, U., and Korte, C.: Oxygen isotope fluctuations in a modern North Sea oyster (Crassostrea gigas) compared with annual variations in seawater temperature: Implications for palaeoclimate studies, Chem. Geol., 277, 160-166, https://doi.org/10.1016/j.chemgeo.2010.07.019, 2010.

Ullmann, C. V., Böhm, F., Rickaby, R. E., Wiechert, U., and Korte, C.: The Giant Pacific Oyster (Crassostrea gigas) as a modern analog for fossil ostreoids: isotopic $(\mathrm{Ca}, \mathrm{O}, \mathrm{C})$ and elemental ( $\mathrm{Mg} / \mathrm{Ca}, \mathrm{Sr} / \mathrm{Ca}, \mathrm{Mn} / \mathrm{Ca}$ ) proxies, Geochem. Geophy. Geosy., 14, 4109-4120, 2013.

van Hinsbergen, D. J., de Groot, L. V., van Schaik, S. J., Spakman, W., Bijl, P. K., Sluijs, A., Langereis, C. G., and Brinkhuis, H.: A paleolatitude calculator for paleoclimate studies, Plos One, 10, e0126946, https://doi.org/10.1371/journal.pone.0126946, 2015.

Van Rampelbergh, M., Verheyden, S., Allan, M., Quinif, Y., Keppens, E., and Claeys, P.: Monitoring of a fast-growing speleothem site from the Han-sur-Lesse cave, Belgium, indicates equilibrium deposition of the seasonal $\delta^{18} \mathrm{O}$ and $\delta^{13} \mathrm{C}$ signals in the calcite, Clim. Past, 10, 1871-1885, https://doi.org/10.5194/cp-10-18712014, 2014.

Vander Putten, E., Dehairs, F., Keppens, E., and Baeyens, W.: High resolution distribution of trace elements in the calcite shell layer of modern Mytilus edulis: Environmental and biological controls, Geochim. Cosmochim. Ac., 64, 997-1011, 2000.

Veizer, J.: Chemical diagenesis of carbonates: theory and application of trace element technique, Stable Isotopes in Sedimentary Geology, 10, 3-100, 1983.

Vellekoop, J., Esmeray-Senlet, S., Miller, K. G., Browning, J. V., Sluijs, A., van de Schootbrugge, B., Damsté, J. S. S., and Brinkhuis, H.: Evidence for Cretaceous-Paleogene boundary bolide "impact winter" conditions from New Jersey, USA, Geology, 44, 619-622, 2016.
Vermeij, G. J.: The oyster enigma variations: a hypothesis of microbial calcification, Paleobiology, 40, 1-13, 2014.

Videt, B.: Dynamique des paléoenvironnements à huîtres du Crétacé supérieur nord-aquitain (SW France) et du Mio-Pliocène andalou (SE Espagne): biodiversité, analyse séquentielle, biogéochimie, Mém. Géosc. Rennes, 108, 1-261, 2004.

Wanamaker Jr, A. D., Kreutz, K. J., Wilson, T., Borns Jr, H. W., Introne, D. S., and Feindel, S.: Experimentally determined $\mathrm{Mg} / \mathrm{Ca}$ and $\mathrm{Sr} / \mathrm{Ca}$ ratios in juvenile bivalve calcite for Mytilus edulis: implications for paleotemperature reconstructions, GeoMar. Lett., 28, 359-368, 2008.

Wang, Q. J., Xu, X. H., Jin, P. H., Li, R. Y., Li, X. Q., and Sun, B. N.: Quantitative reconstruction of Mesozoic paleoatmospheric $\mathrm{CO}_{2}$ based on stomatal parameters of fossil Baiera furcata of Ginkgophytes, Geological Review, 59, 1035-1045, 2013.

Wang, W.-X. and Fisher, N. S.: Assimilation of trace elements and carbon by the mussel Mytilus edulis: effects of food composition, Limnology and Oceanography, 4, 197-207, 1996.

Watanabe, T., Winter, A., and Oba, T.: Seasonal changes in sea surface temperature and salinity during the Little Ice Age in the Caribbean Sea deduced from $\mathrm{Mg} / \mathrm{Ca}$ and ${ }^{18} \mathrm{O} /{ }^{16} \mathrm{O}$ ratios in corals, Mar. Geol., 173, 21-35, 2001.

Weiner, S. and Dove, P. M.: An overview of biomineralization processes and the problem of the vital effect, Rev. Mineral. Geochem., 54, 1-29, 2003.

Wisshak, M., Correa, M. L., Gofas, S., Salas, C., Taviani, M., Jakobsen, J., Freiwald, A.: Shell architecture, element composition, and stable isotope signature of the giant deep-sea oyster Neopycnodonte zibrowii sp. $\mathrm{n}$. from the NE Atlantic, Deep-Sea Res. Pt. I, 56, 374-407, 2009.

Woelders, L., Vellekoop, J., Kroon, D., Smit, J., Casadío, S., Prámparo, M. B., Dinarès-Turell, J., Peterse, F., Sluijs, A., Lenaerts, J. T. M., and Speijer, R. P.: Latest Cretaceous climatic and environmental change in the South Atlantic region, Paleoceanography, 32, 2016PA003007, https://doi.org/10.1002/2016PA003007, 2017.

Woo, K.-S., Anderson, T. F., and Sandberg, P. A.: Diagenesis of skeletal and nonskeletal components of mid-Cretaceous limestones, J. Sediment. Res., 63, 18-32, 1993. 